\title{
Six new species of Dolichopeza (Nesopeza) from China (Diptera: Tipulidae)
}

\author{
Qiu-Lei MEN ${ }^{1, *)}$, Yan $\mathrm{DONG}^{2)}$, Chao $\mathrm{YUE}^{3)}$, Yong $\mathrm{CAO}^{1)}$ \& Zi-Kun XU ${ }^{4)}$ \\ ${ }^{1)}$ School of Life Sciences, Provincial Key Laboratory of the Biodiversity Study and Ecology Conservation in Southwest Anhui, Research Center of \\ Aquatic Organism Conservation and Water Ecosystem Restoration in Anhui Province, Anqing Normal University, Anqing, Anhui 246011, China; \\ e-mail: menqiulei888@126.com \\ 2) Library, Anqing Normal University, Anqing, Anhui 246011, China \\ 3) School of Life Sciences and Technology, Nanyang Normal University, Nanyang, Henan 473061, P. R. China \\ 4) Administrative Bureau of Wuyishan National Nature Reserve, Wuyishan, Fujian 354399, P. R. China \\ ") Corresponding author.
}

Accepted:

$5^{\text {th }}$ December 2018

Published online: $14^{\text {th }}$ December 2018

\begin{abstract}
Six new species of Dolichopeza Curtis, 1825, subgenus Nesopeza Alexander, 1914, are described and illustrated: $D$. (N.) incisuraloides sp. nov., $D$. (N.) jiangjinensis sp. nov., $D$. (N.) lipingensis sp. nov., $D$. (N.) medionodosa sp. nov., $D$. (N.) multidentata sp. nov., and $D$. (N.) setilobatoides sp. nov. Dolichipeza (N.) incisuralis Alexander, 1940 is redescribed and illustrated based on additional morphological characters. The female internal reproductive systems of $D$. ( N .) incisuraloides sp. nov. and $D$. (N.) multidentata sp. nov. are documented. A key is provided to separate all known species of Nesopeza from China.
\end{abstract}

Key words. Diptera, Tipuloidea, Tipulidae, new species, female internal reproductive system, semen pump, taxonomy, China

Zoobank: http://zoobank.org/urn:1sid:zoobank.org:pub:A4D7D0F9-FF6A-4374-804B-17750DDC774E

(C) 2018 The Authors. This work is licensed under the Creative Commons Attribution-NonCommercial-NoDerivs 3.0 Licence.

\section{Introduction}

Dolichopeza (Nesopeza) was established by AleXANDER (1914) based on Dolichopeza gracilis de Meijere, 1911 from Indonesia by original designation. It was originally treated as a genus, but subsequently placed into genus Dolichopeza Curtis, 1825 as its subgenus by ALEXANDER (1931). The subgenus was characterized as follows: antenna 13-segmented, scape cylindrical with a few long hairs, pedicel oval-cylindrical, the first flagellomere elongated, the remaining ones gradually shorter; palpus with the first segment equal in length to the other three segments together; wing with first $\mathrm{M}_{2}$ lacking, the radial sector elongated and angulated at origin, subequal in length to $R_{3}$, Rs relatively elongated (Alexander 1914). It is a relatively large subgenus with 124 valid species according to the current Catalogue of the Crane Flies of the World (Oosterbroek 2017) as of the end of 2017. Dolichopeza (Nesopeza) is the dominant subgenus in the Oriental Region with 118 known species. The remaining known species are restricted to the East-Palaearctic and Australian Regions with six and five, respectively. The Chinese fauna of Dolichopeza (Nesopeza) is poorly represented with only 22 species (Oosterbroek 2017). While sorting crane flies specimens collected from Fujian, Chongqing and Shaanxi, six new species of Dolichopeza (Nesopeza) were discovered. In the present paper, the new taxa are described and illustrated. The male of Dolichopeza ( $\mathrm{Ne}$ sopeza) incisuralis Alexander, 1940 is redescribed and illustrated with new morphological characters. The female internal reproductive systems of $D$. (N.) incisuraloides sp. nov. and $D$. (N.) multidentata sp. nov. are documented for better understanding of the morphological diversity of reproductive organs in crane flies. A key to known species from China is also provided.

\section{Material and methods}

The specimens examined in the present study were collected from a variety of locations in China, including Fujian, Chongqing and Shaanxi. The specimens were collected by sweep net, Malaise trap and light trap. The hypopygium of male and ovipositor of female were removed and macerated in $10 \% \mathrm{NaOH}$ for one hour at $50^{\circ} \mathrm{C}$ 
water bath, observed in glycerin and illustrated under a SOIF XTZ-E stereomicroscope (SOIF, Shanghai, China), finally preserved in glycerin jelly in $0.20 \mathrm{ml}$ centrifuge tubes. The female internal reproductive systems were dissected in water, and then examined and drawn using the same stereomicroscope. Dissection was performed with the aid of two very fine needles, a pair of scissors and a pair of fine-tipped tweezers. Photographs of the body parts of adults were obtained using a SOIF XTZ-E stereomicroscope (SOIF, Shanghai, China). All measurements are given in millimeters $(\mathrm{mm})$, made with the aid of a digital caliper. The terminology and methods of description and illustration followed FrommER (1963), AlEXANDER \& Byers (1981), and DE Jong (2017). All specimens are deposited in the laboratory of systematics and evolution, the Provincial Key Laboratory of the Biodiversity Study and Ecology Conservation in Southwest Anhui Province, Anqing Normal University, Anhui Province, China. The first author was responsible for the taxonomic portion of this paper, thus is the author of the new species.

The key was principally constructed based on descriptions in the literature. The characters used in the key rely primarily on colors of body parts, structure of genitalia and variation of veins.

\section{Taxonomy}

\section{Key to species of Dolichopeza (Nesopeza) in China}

1 Wing with ground color gray, cell c and outer end of cell sc whitish, brown areas distributed in prearcular and postarcular regions, one third of length of cell $\mathrm{r}$, origin of Rs, cells $\mathrm{r}_{2}, \mathrm{r}_{3}, \mathrm{r}_{5}$ and $\mathrm{m}_{1}$, each with a conspicuously white enclosed area near outer end (see AleXANDER 1928a: 456).

D. (N.) circe (Alexander, 1928)

- Wing with ground color or marking pattern not as above.

2 Wing with dark markings extended from costal area.

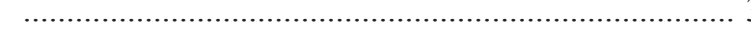

- Wing without marking pattern described as above. ... 4

3 Cell $\mathrm{m}_{1}$ longer than its petiole. ................................. 5

- Cell $\mathrm{m}_{1}$ not longer than its petiole. ............................ 6

4 Cell $\mathrm{m}_{1}$ shorter than its petiole (see AlEXANDER 1937a: 370, Pl. I, fig. 4). ..... D. (N.) fabella Alexander, 1937

- Cell $\mathrm{m}_{1}$ not shorter than its petiole.

5 Sc ending approximately opposite $4 / 5$ of the length of Rs, the latter without basal spur (see DE MEIJERE 1911: $60)$. D. (N.) gracilis de Meijere, 1911

- Sc ending at the same level as the end of Rs, the latter bearing basal spur (see AlexAnder 1935a: 137, Pl. I, fig. 3).

D. (N.) profundemarginata Alexander, 1935

6 Hypopygium with the tergal arms erose apically; cell $\mathrm{m}_{1}$ subequal in length to its petiole (see ALEXANDER 1956: 657). ... D. (N.) tuberculifera Alexander, 1956

- Hypopygium without such arms; cell $\mathrm{m}_{1}$ shorter than its petiole.

7 Sternite eight produced caudad into a stout lobe, on either side of median line with a further small lobule bearing a group of short setae, median area broad and membranous with a group of microscopic setulae (see AleXANDER 1949: 191).

D. (N.) magnisternata Alexander, 1949

- Sternite eight not as above (see AlEXANDER 1949). ... 8

8 Outer gonostylus curved medially (see AleXANDER 1931: 340, Pl. I, figs 21-23).

D. (N.) subgeniculata Alexander, 1931

- Outer gonostylus straight, expanded in the proximal part (see SAVCHENKo 1983: 443, fig. 160).

D. (N.) geniculate (Alexander, 1918)

9 Cell $\mathrm{m}_{1}$ at least 1.5 times longer than its petiole. .... 10

- Cell $\mathrm{m}_{1}$ less than 1.5 times longer than its petiole. ... 11

10 Tergite nine with four processes (see SAVCHENKO 1983: 445, fig. 162)...... D. (N.) tarsalis (Alexander, 1919)

- Tergite nine with fewer than four processes. ......... 12

12 Wing with the costal area and tip darker than ground color. 14

- Wing with the costal area and tip not darker than ground color. 15

13 Tibiae white (see AleXANDER 1956: 658).

D. (N.) subalbitibia Alexander, 1956

- Tibiae not white. ..................................................... 13

14 Sternite nine produced caudad into a conspicuous lobe; wing with a gray suffusion (see AlEXANDER 1932: 105, Pl. II, fig. 23).

D. (N.) francki Alexander, 1932

- Sternite nine not produced into such lobe; wing with a strong brownish tinge (see ALEXANDER 1928b: 457, Pl. II, fig. 2). ....... D. (N.) trichopyga (Alexander, 1928)

15 Tarsi and tibiae of the same color. ......................... 16

- Tarsi and tibiae not of the same color. ................... 17

16 Sc ending not more than opposite half the length of

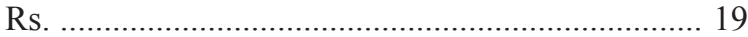

- Sc ending more than opposite half the length of Rs.

17 Caudal border of tergite nine trilobed (see ALEXANDER 1949: 190). ...... D. (N.) lohfauensis Alexander, 1949

- Caudal border of tergite nine bilobed (see AlexAnder 1940: 126, fig. 8).

D. (N.) leucocnemis Alexander, 1940

18 Gonocoxite very elongated with long setae at apex (see AlexAnder 1929a: 519, Pl. II, fig. 25).

D. (N.) basistylata (Alexander, 1929)

- Gonocoxite not elongated, without such long setae.

19 Outer gonostylus with a node in the middle part; caudal margin of aedeagal guide with median process obliquely truncated apically (Figs 61, 62, 64).

D. (N.) medionodosa Men sp. nov.

- Outer gonostylus without such node; caudal margin of aedeagal guide with median process rounded apically (Figs 51-53). .... D. (N.) multidentata Men sp. nov.

20 Cell $\mathrm{m}_{1}$ subequal in length to its petiole, the latter distinctly longer than $\mathrm{M}_{1+2+3}$ (see AleXANDER 1928: 458, Pl. I, fig.3). ....... D. (N.) taiwania (Alexander, 1923)

- Cell $\mathrm{m}_{1}$ distinctly longer than its petiole, the latter slightly shorter than $\mathrm{M}_{1+2+3}$ (Fig. 17).

D. (N.) setilobatoides Men sp. nov. 
21 Tip of tibiae of the same color as the remaining. .... 21

- Tip of tibiae of different color than the remaining. .... .. 22

22 Caudal margin of tergite nine trilobed, lateral angles not rounded (Fig. 31).

D. (N.) incisuraloides Men sp. nov.

- Caudal margin of tergite nine not trilobed, lateral angles rounded apically (see ALEXANDER 1935b: 351, Pl. II, fig. 35).

D. (N.) lugubrivestis Alexander, 1935

23 Tibiae with a tip darker in coloration than the remaining.

23

- Tibiae with a tip brighter in coloration than the remaining.

24 Basal flagellar segments pale brown, the remaining flagellar segments dark brown; inner gonostylus without a lateral lobule (see ALEXANDER 1940: 19: 128, fig. 9; Fig. 25)

D. (N.) incisuralis Alexander, 1940
- Flagellum black; inner gonostylus with a lateral lobule (see AlEXANDER 1937b: 26, fig. 34).

D. (N.) kulingensis Alexander, 1937

25 Sc nearly two times longer than the basal section of $\mathrm{R}_{4+5}$ (see AleXANDer 1949: 189).

D. (N.) adela Alexander, 1949

- Sc more than four times longer than the basal section of $\mathrm{R}_{4+5}$. 25

26 Outer gonostylus with apex truncated (see AlEXANDER 1929b: 323, Pl. I, fig. 5).

D. (N.) rantaizana (Alexander, 1929)

- Outer gonostylus with apex obtuse.

27 Outer gonostylus with three or four very elongated bristles; median lobe of tergite nine cone-shaped in dorsal view (see AlEXANDER 1942: 166, fig. 7).

D. (N.) tinkhamiana Alexander, 1942

- Outer gonostylus without elongated bristles as described above; median lobe of tergite nine not coneshaped in dorsal view. 27

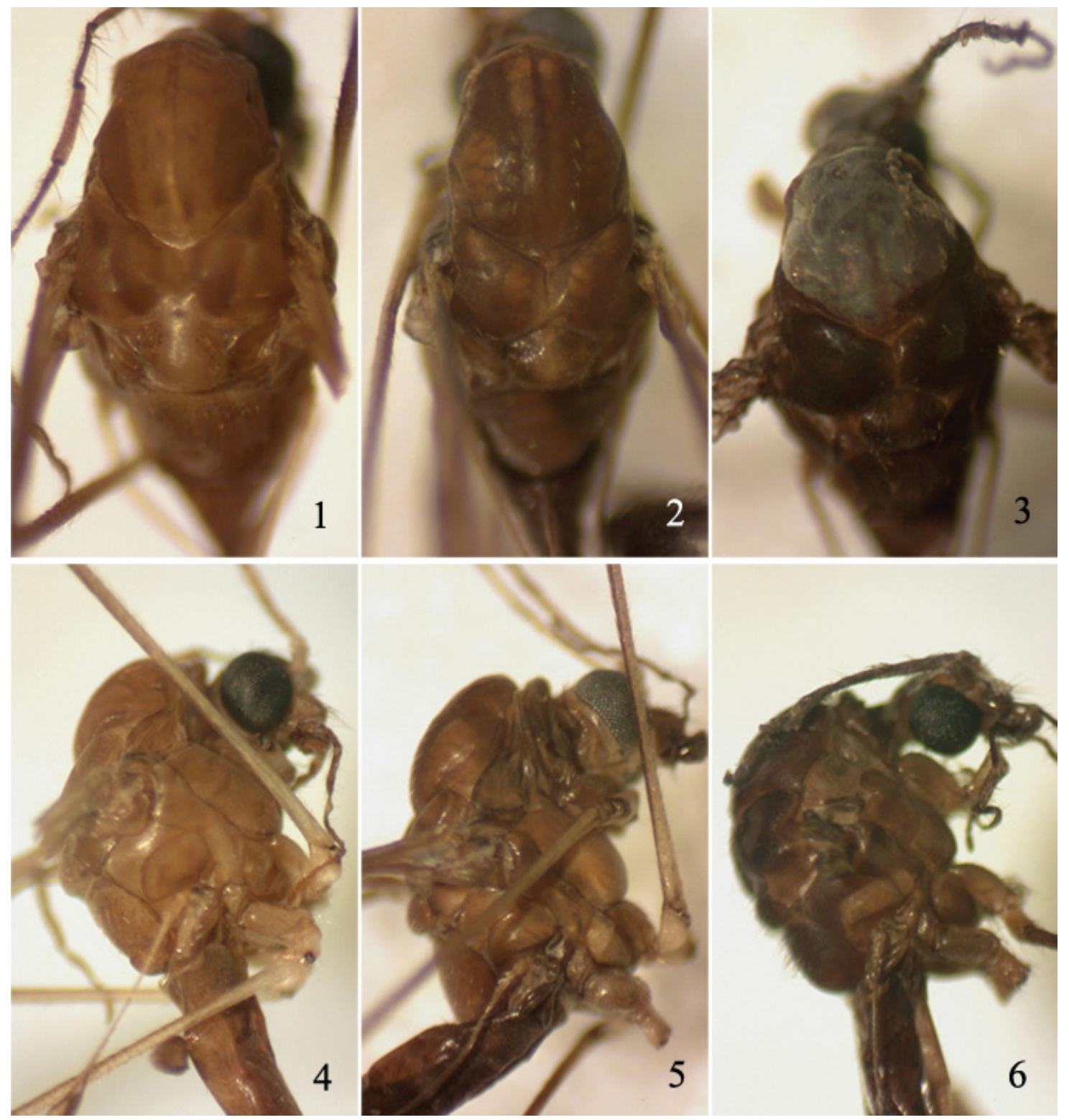

Figs 1-6. thorax, dorsal and lateral views. 1, 4 - Dolichopeza (Nesopeza) incisuralis Alexander, 1940; 2, 5 - D. (N.) incisuraloides sp. nov.; 3, 6 D. (N.) setilobatoides sp. nov. 
28 Sternite nine with a pair of processes directed caudad; aedeagal guide narrowed to apex (Figs 65, 69).

D. (N.) jiangjinensis Men sp. nov.

- Sternite nine without such process; aedeagal guide expanded at apex (Figs 72, 77).

\section{D. (N.) lipingensis Men sp. nov.}

\section{Dolichopeza (Nesopeza) incisuralis Alexander, 1940}

(Figs 1, 4, 15, 22-29)

Dolichopeza (Nesopeza) incisuralis Alexander, 1940: 128 (original description).

Dolichopeza (Nesopeza) incisuralis: Li et al. (2016: 9-36).

Type locality. Tianmushan Mountain, Zhejiang Province, China. Material examined. China: Fujian Province: $3 \hat{\jmath} \hat{\jmath}$, Guadun, Wuyishan National Nature Reserve, $27^{\circ} 44^{\prime} \mathrm{N}, 117^{\circ} 38^{\prime} \mathrm{E}, 14 . \mathrm{v} .2017$, Qiulei Men.

Diagnosis. Generally yellowish-brown in coloration. Prescutum yellowish-brown with four darker stripes. Wing suffused with light yellowish-brown. Tergite nine with a big median lobe and a pair of small triangular lobes. Outer gonostylus broadened medially, inner gonostylus with basal beak truncate.

Redescription. Male. Length: body 9.0-9.2 mm, wing 9.0-9.2 mm, antenna 4.5-4.6 mm.

Head. Rostrum short, grayish-brown. Nasus lacking. Antenna with scape yellow, elongated and cylindrical, pedicel yellowish, darker than scape, very short, flagellum yellowish-brown, flagellomere gradually shorter in length. Palpus with the first segment yellowish-brown, remaining segments brown. Head yellowish-brown, occiput with median region slightly darker in coloration.

Thorax. Pronotum yellowish-brown (Figs 1, 4). Prescutum yellowish-brown with four darker stripes, median stripes divided into two parts by yellow mid-line, lateral stripes slightly longer than half length of median stripe (Fig. 1). Scutum, scutellum and postnotum yellowish-brown (Fig. 4).

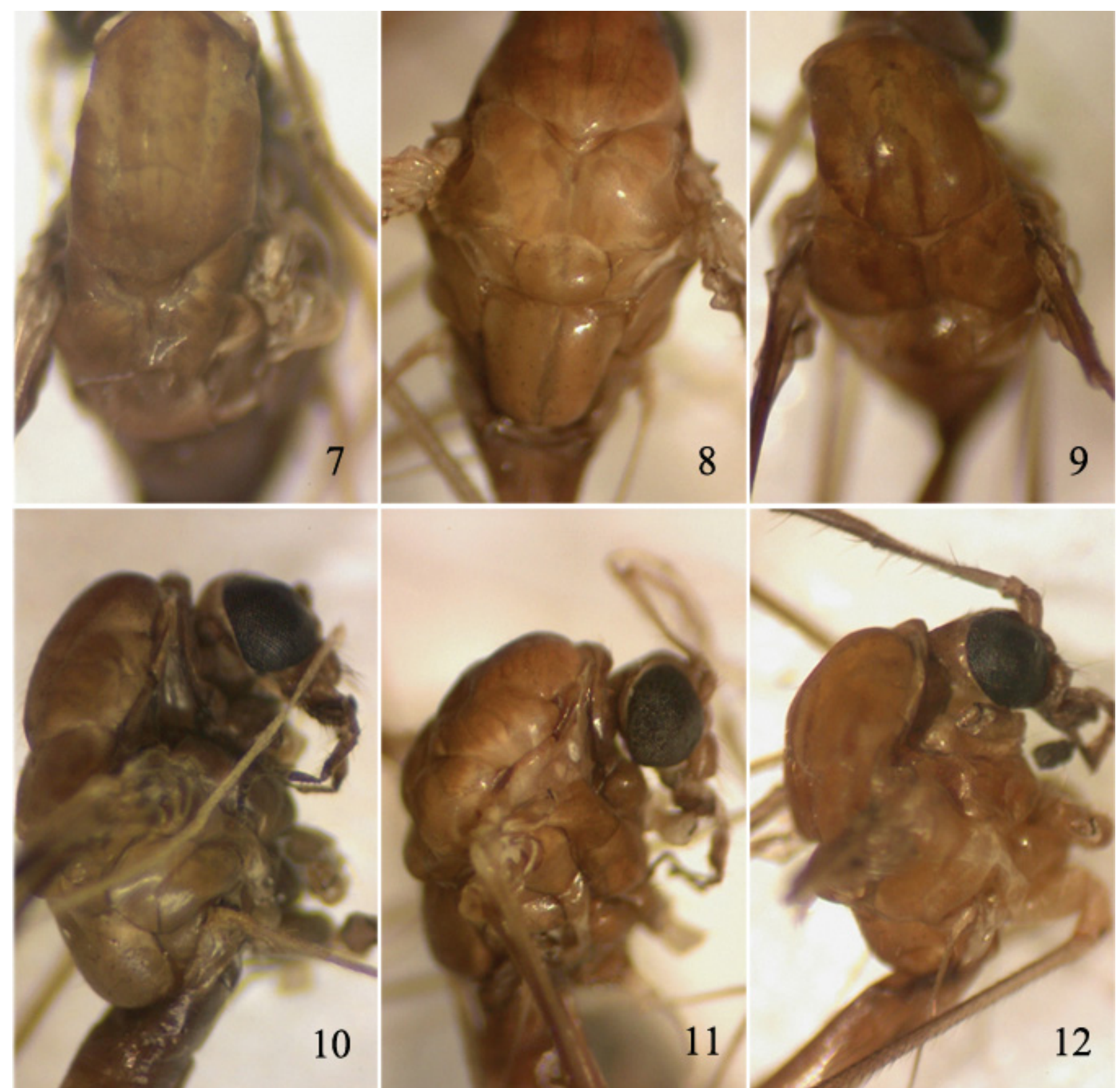

Figs 7-12. Thorax, dorsal and lateral views. 7, 10 - Dolichopeza (Nesopeza) multidentata sp. nov.; 8, 11 - D. (N.) medionodosa sp. nov.; 9, 12 - D. (N.) jiangjinensis sp. nov. 


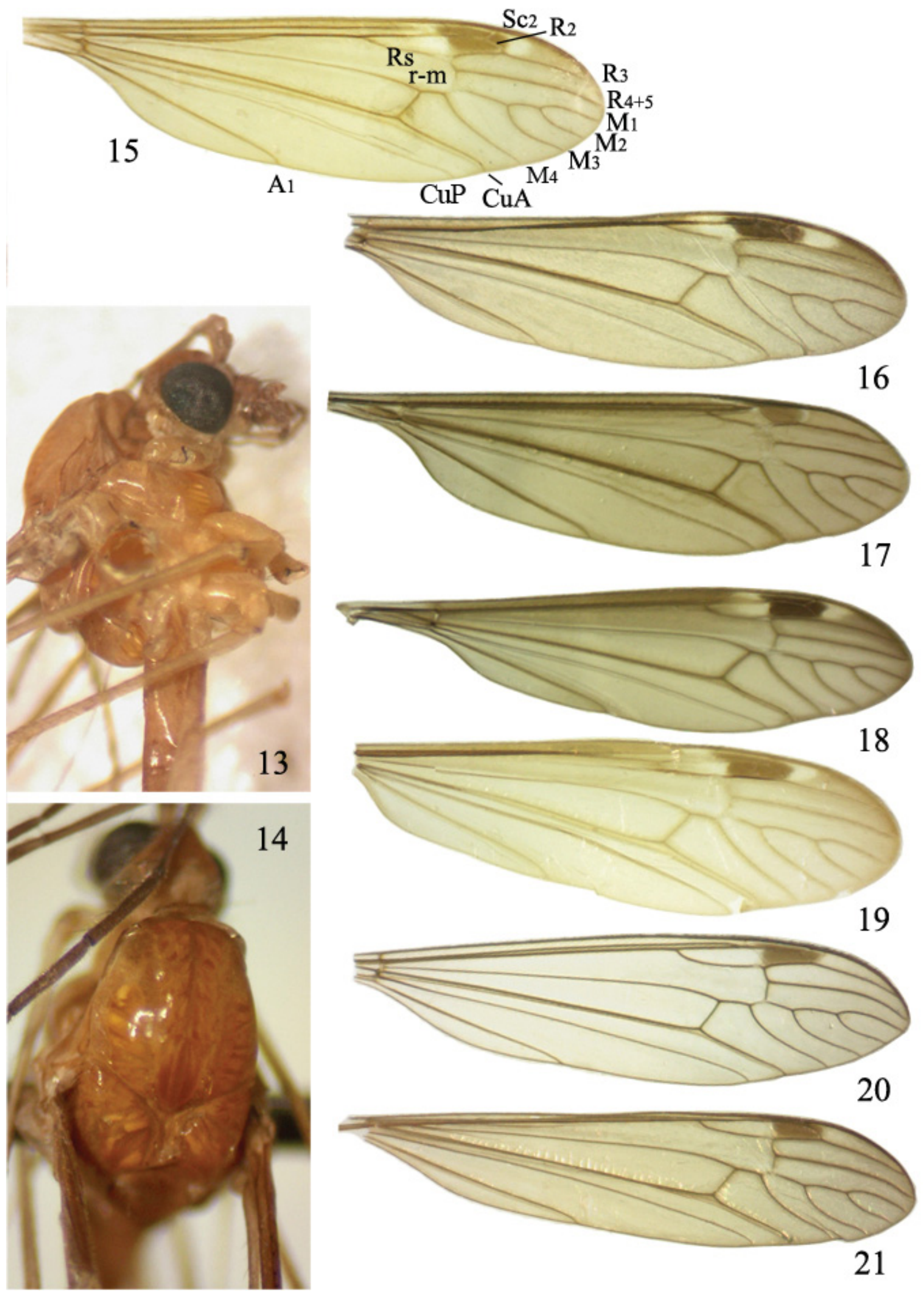

Figs 13-21. Thorax, dorsal and lateral views, and wing. 13, 14 - Dolichopeza (Nesopeza) lipingensis sp. nov.; 15 - D. (N.) incisuralis Alexander, 1940; $16-D$. (N.) incisuraloides sp. nov.; 17 - D. (N.) setilobatoides sp. nov.; 18 - D. (N.) multidentata sp. nov.; 19 - D. (N.) medionodosa sp. nov.; 20 - D. (N.) jiangjinensis sp. nov.; $21-D$. (N.) lipingensis sp. nov. 
Pleuron yellowish-brown, without dorsal-longitudinal stripe or distinct marks (Fig. 4). Halter with stem yellowish-brown, knob slightly darker. Leg with coxa yellowish-brown, same color as body, trochanter and femur yellow, tibia white with basal portion slightly yellow, tip of tibia yellowish-brown, tarsus wholly white. Wing with light yellowish-brown tinge, cells $\mathrm{c}$ and sc not darker than ground color, stigma dark brown with both ends brighter; veins brown, Sc ending about opposite $3 / 4$ of length of Rs, the latter relatively elongated, $\mathrm{R}_{3}$ slightly curved, about twice as long as $\mathrm{R}_{2+3}$, cell $\mathrm{m}_{1} 1.7$

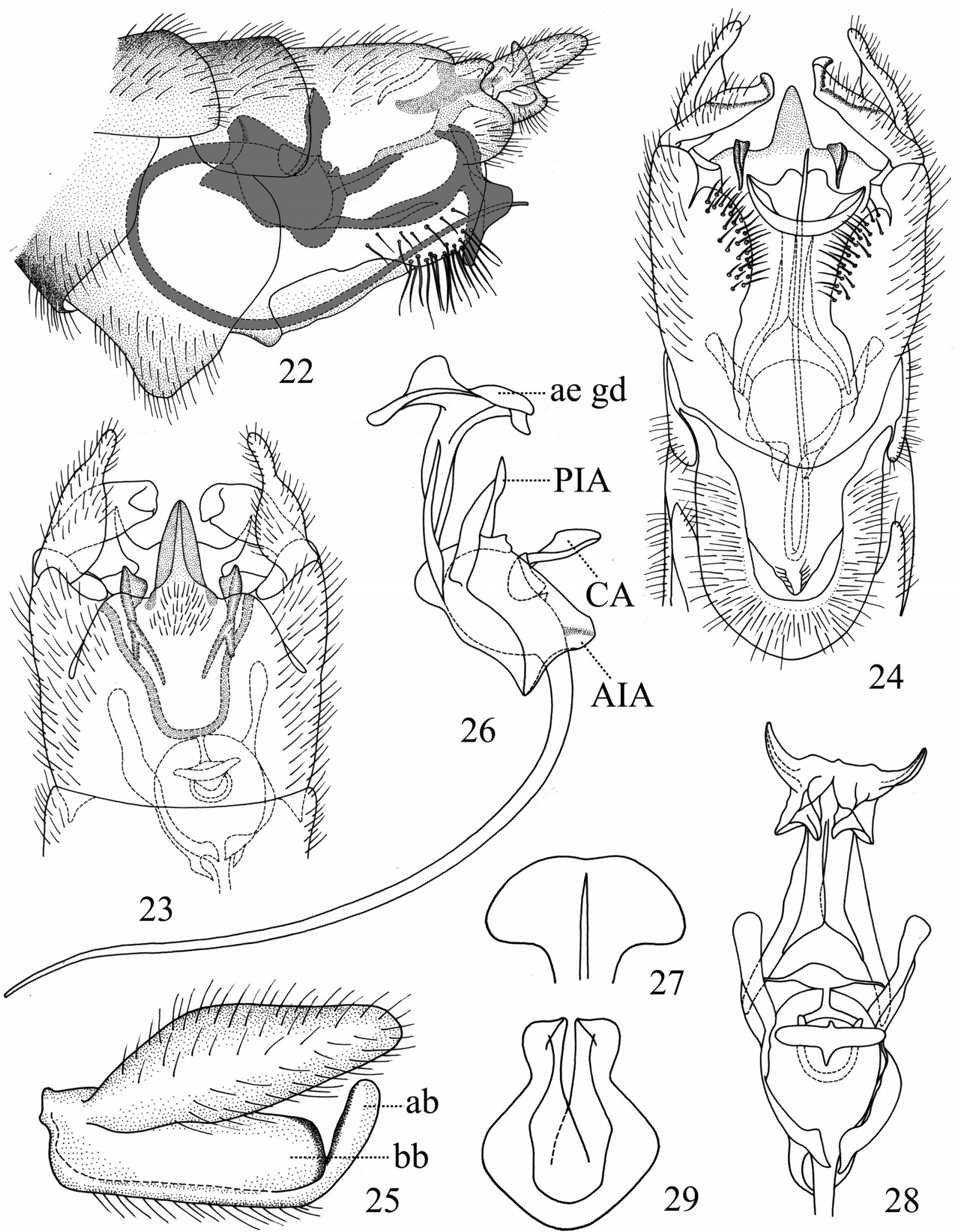

Figs 22-29. Dolichopeza (Nesopeza) incisuralis Alexander, 1940. 22 - hypopygium, lateral view; 23 - hypopygium, dorsal view; 24 - hypopygium, ventral view; 25 - outer gonostylus and inner gonostylus; 26 - semen pump, lateral view; 27 - compressor apodeme, dorsal view; 28 - semen pump, dorsal view; 29 - ventral surface of aedeagal guide. Abbreviations: ab - apical beak; ae gd - aedeagal guide; AIA - anterior immovable apodeme; $\mathrm{bb}$ - basal beak; CA - compressor apodeme; PIA - posterior immovable apodeme. Gray region indicates the structure and position of semen pump. 
times longer than its petiolate, $\mathrm{r}-\mathrm{m}$ distinctly longer than basal section of $\mathrm{R}_{4+5}$ (Fig. 15).

Abdomen yellowish-brown postmedially with yellow ring on segments one to five. Remaining segments and hypopygium yellowish-brown. Hypopygium broad and compressed, with tergite nine conspicuously trilobed, median one distinctly longer than the other two, the latter small and triangular, with forked extension produced into genital chamber (Figs 22-24). Sternite nine with median region produced into membranous extension, many long setae generated from its hind margin (Fig. 24). Outer gonostylus dilated medially, obtuse apically (Figs 22-25). Inner gonostylus with apical beak slender, with basal beak truncate (Figs 22-25).

Semen pump with anterior immovable apodeme broadened, extended downward (Figs 26, 28). Compressor apodeme fan-shaped, slightly emarginate medially (Figs 27, 28). Posterior immovable apodeme subequal in length to compressor apodeme, rod-shaped in dorsal view, acute apically in lateral view (Figs 26, 28). Aedeagal guide extending from semen pump posteriorly, connecting with ventral wall of genital chamber; expanded apically and heptagonal in caudal view, caudal lobes horn-shaped in dorsal view (Figs 26, 28, 29). Aedeagus tapering toward end (Fig. 26).

Distribution. China: Fujian Province (new record); Zhejiang Province.

\section{Dolichopeza (Nesopeza) incisuraloides Men sp. nov. (Figs 2, 5, 16, 30-40)}

Type locality. Simianshan Mountain, Chongqing, China, $28^{\circ} 39^{\prime} \mathrm{N}$, $106^{\circ} 24^{\prime} \mathrm{E}$.

Type material. Holotype: CHINA: ChongqING: Simianshan Mountain, 17.v.2017, coll. Guoxi Xue, Chao Zhang. Paratypes: 2 ô 1 , same data as holotype.

Diagnosis. Generally grayish-brown. Prescutum grayish-brown with four yellowish stripes. Wing grayish-brown with dark brown stigma. Leg with coxa and trochanter light brown, femur light brown with dark brown tip, tibia and tarsus wholly white. Tergite nine conspicuously trilobed, median one bigger than the others. Outer gonostylus narrowed, slightly dilated medially, inner gonostylus with basal beak truncate, with apical beak relatively broadened, obliquely truncate.

Description. Male. Length: body 7.0-7.2 mm, wing 7.2-7.4 mm, antenna 3.4-3.6 mm.

Head. Rostrum grayish-brown. Nasus lacking. Antenna with scape, pedicel and first flagellomere light yellowish-brown, remaining flagellomeres dark brown, flagellomere gradually shorter in length. Palpus dark brown. Head grayish-brown, occiput with median region slightly darker in coloration.

Thorax. Pronotum grayish-brown (Figs 2, 5). Prescutum grayish-brown with four yellow stripes, median stripes divided into two parts by grayish-brown mid-line, lateral stripes slightly longer than half length of median stripe (Fig. 2). Scutum grayish-brown. Scutellum and postnotum grayish-brown with middle region slightly yellow (Fig. 2). Pleuron grayish-brown, without dorsal-longitudinal stripe or distinct markings (Fig. 5). Halter with stem grayish-brown, knob dark brown. Leg with coxa and trochanter light brown, femur light brown with dark brown tips, tibia and tarsus wholly white. Wing with grayish-brown suffusion, cells c and sc not suffused with darker color, stigma dark brown with both ends brighter, anterior brighter region almost covering cell rs; veins brown, Sc ending about opposite terminal of Rs, $\mathrm{R}_{3}$ slightly curved, about twice as long as $\mathrm{R}_{2+3}$, cell $\mathrm{m}_{1} 1.6$ times longer than its petiolate, $\mathrm{r}-\mathrm{m}$ slightly longer than basal section of $\mathrm{R}_{4+5}$ (Fig. 16).

Abdomen dark brown with light brown ring on each segment medially. Hypopygium dark brown. Hypopygium with tergite nine conspicuously trilobed, median one distinctly longer than the others, the latter small and acute apically (Figs 30, 31). Outer gonostylus narrowed, dilated medially, obtuse apically (Figs 30-32). Inner gonostylus with basal beak truncate, with apical beak relatively broadened, obliquely truncate (Figs 30-32).

Semen pump with anterior immovable apodeme broadened (Figs 33, 35). Compressor apodeme fan-shaped, slightly emarginated, median ridge very developed (Fig. 34). Posterior immovable apodeme slightly shorter than compressor apodeme, finger-shaped in dorsal view, slightly curved in lateral view (Figs 33, 35). Aedeagal guide extending from semen pump posteriorly, connecting with ventral wall of genital chamber, expanded apically and rabbit-head-shaped in caudal view (Figs 33, 35). Aedeagus relatively thick, gradually narrowed to apex from distal third (Fig. 33).

Female. Length: body $9.4-9.6 \mathrm{~mm}$, wing 9.6-9.8 mm, antenna $1.8-2.0 \mathrm{~mm}$.

Antenna relatively short, scape grayish-brown, elongated, pedicel grayish-brown, very short, flagellum slightly darker. Leg with coxa and trochanter light brown, femur grayish-brown with dark brown tips, tibia light grayish except both ends whitish, and tarsus white with grayish base. Abdomen generally grayish-brown, tergites one to eight with broad yellowish rings in middle areas of tergites, tergite nine and ten wholly brown (Figs 37, 38). Sternites grayish-brown. Ovipositor brown (Figs 37, 38). Cercus long, acinacifoliate (Figs 37, 38). Hypogynial valve darker in coloration, simple, slightly surpassing caudal margin of tergite ten (Figs 37, 38).

Internal reproductive system. Consisting of bursa copulatrix leading to functional spermatheca, three spermathecae with respective spermatheca ducts, and vaginal apodeme (Fig. 39). Bursa copulatrix relatively elongated, narrowed, terminating in swollen functional spermatheca (Fig. 39). Spermatheca spherical (Fig. 39). Spermatheca duct slender and flexible, arising from median region of bursa copulatrix (Fig. 39). Spermatheca ducts attached to bursa copulatrix separately, but in close proximity (Fig. 39). Vaginal apodeme broad basally, gradually narrowed to very acute apex (Figs 39, 40). Female internal reproductive system with copulatory opening on ventral side of sternite nine (Fig. 39).

Differential diagnosis. This new species is externally similar to $D$. (N.) incisuralis in the venation of wing, the shapes of inner gonostylus and processes on tergite nine. It 


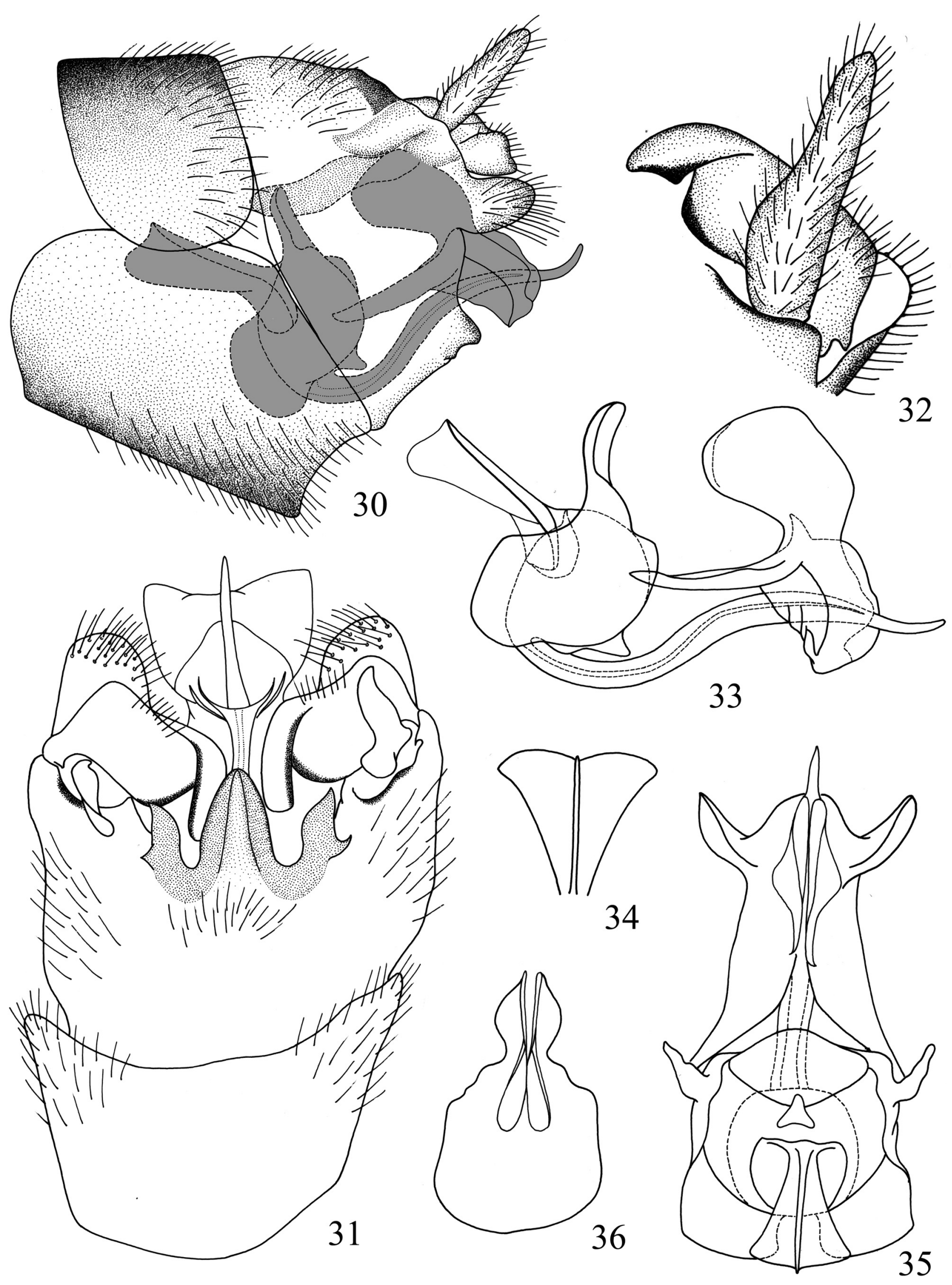

Figs 30-36. Dolichopeza (Nesopeza) incisuraloides sp. nov. 30 - hypopygium, lateral view; 31 - hypopygium, dorsal view; 32 - outer gonostylus and inner gonostylus; 33 - semen pump, lateral view; 34 - compressor apodeme, dorsal view; 35 - semen pump, dorsal view; 36 - ventral surface of aedeagal guide. Gray region indicates the structure and position of semen pump. 


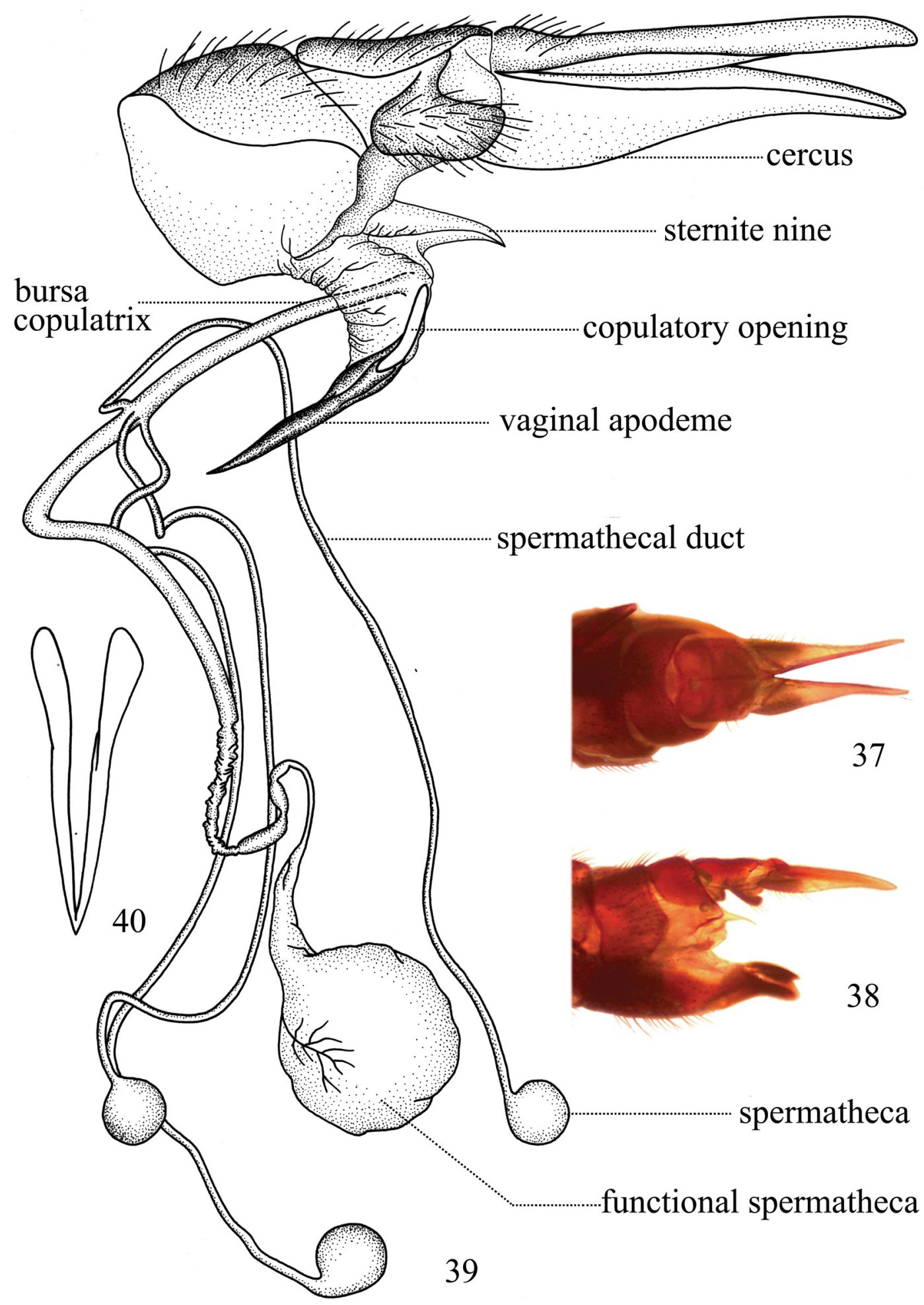

Figs 37-40. Dolichopeza (Nesopeza) incisuraloides sp. nov. 37 - ovipositor, dorsal view; 38 - ovipositor, lateral view; 39 - internal reproductive system; 40 - vaginal apodeme, ventral view.

can be easily distinguished from the latter by darker body color, narrower outer gonostylus, the anterior immovable apodeme not expanded downward (expanded downward in $D$. (N.) incisuralis), the compressor apodeme having a developed middle ridge (not bearing such middle ridge in $D$. (N.) incisuralis), and the aedeagus gradually tapered to apex (gradually narrowed only from the distal third in $D$.
(N.) incisuralis). There is also a noticeable difference in the shape of aedeagal guide as illustrated in Figures 33 and 35. Etymology. The specific epithet is based on the name of the related species, $D$. (N.) incisuralis, with the Latin suffix '-oides', referring to the morphological similarity of the new species to $D$. (N.) incisuralis.

Distribution. China: Chongqing. 


\section{Dolichopeza (Nesopeza) setilobatoides Men sp. nov. (Figs 3, 6, 17, 41-46)}

Type locality. Taohuajian, Wuyishan National Nature Reserve, Fujian Province, China, $27^{\circ} 44^{\prime} \mathrm{N}, 117^{\circ} 38^{\prime} \mathrm{E}$.

Type material. Holotype: $\hat{\jmath}$, CHINA: Fujan Province: Taohuajian, Wuyishan National Nature Reserve, 19.v.2017, coll. Qiulei Men. PARATYPES: $2 \hat{\jmath} \hat{\jmath}$, same data as holotype.
Diagnosis. Generally brown. Prescutum brown with four dark brown stripes. Wing strongly suffused with grayish-brown, stigma light brown. Leg with coxa and trochanter yellowish-brown, femur dark brown, tibia yellowish-brown, tarsus yellowish-brown except the white tip. Tergite nine conspicuously trilobed, the median one cone-shaped. Outer gonostylus broadened in basal half,
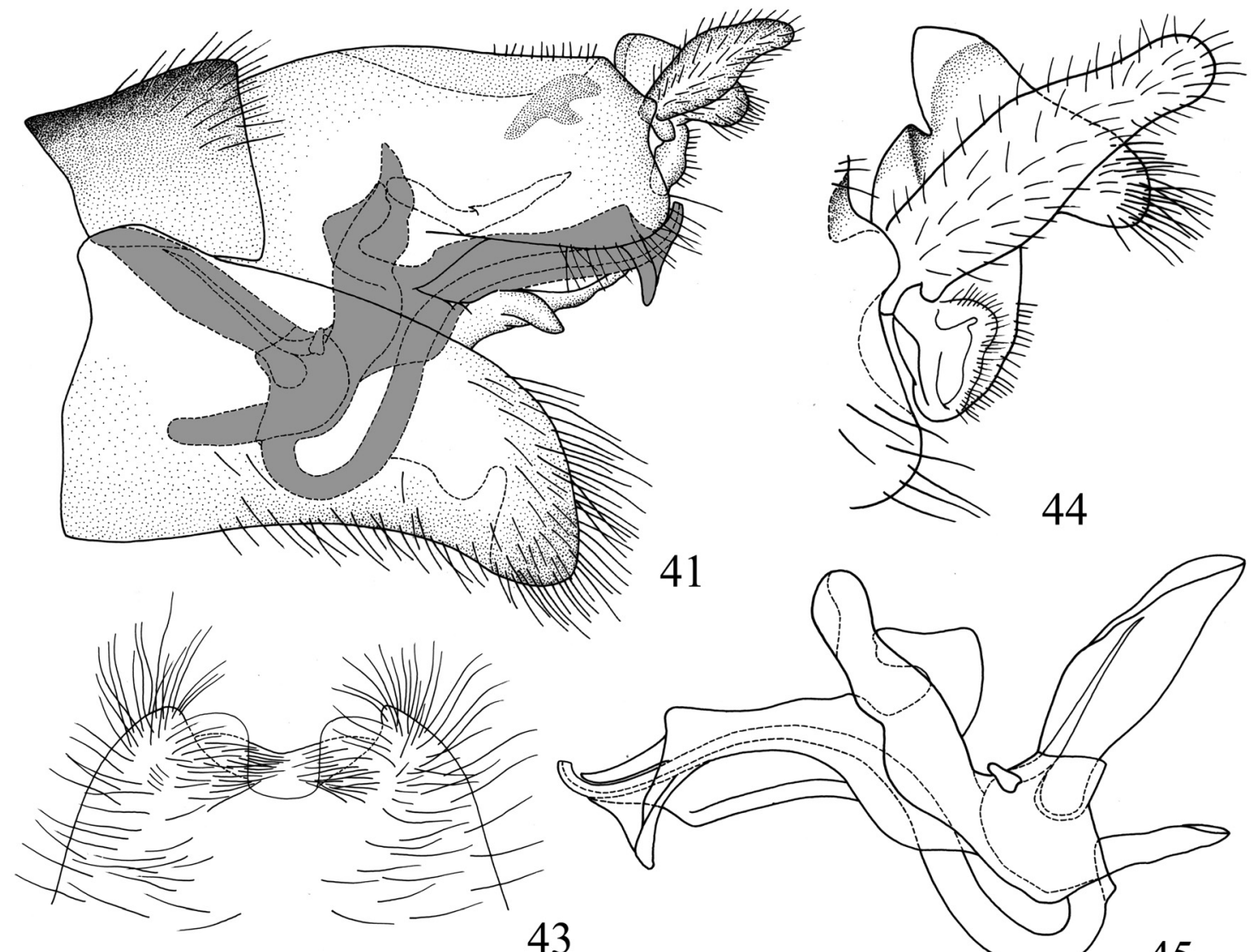

41
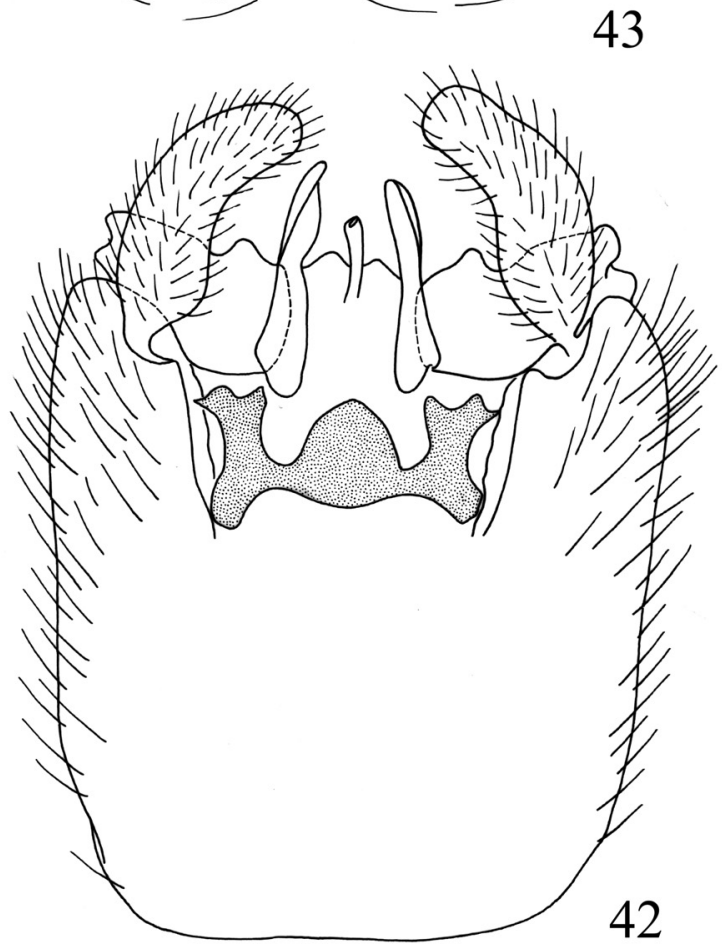

45

42

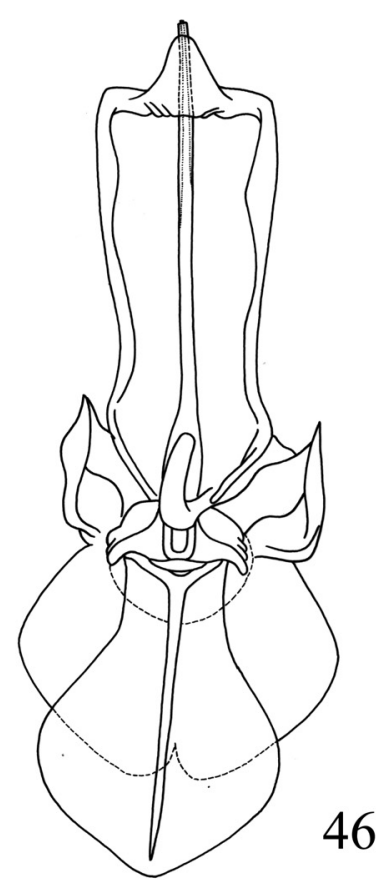

Figs 41-46. Dolichopeza (Nesopeza) setilobatoides sp. nov. 41 - hypopygium, lateral view; 42 - hypopygium, dorsal view; 43 - sternite eight, ventral view; 44 - outer gonostylus and inner gonostylus; 45 - semen pump, lateral view; 46 - semen pump, dorsal view. Gray region indicates the structure and position of semen pump. 
narrowed in apical half, rounded apically, inner gonostylus with two beaks, conspicuously concaved at hind margin. Description. Male. Length: body 10.0-10.2 mm, wing $10.2-10.4 \mathrm{~mm}$, antenna $2.2-2.4 \mathrm{~mm}$.

Head. Rostrum short, brown. Nasus lacking. Antenna dark brown, scape elongated and cylindrical, pedicel very short, flagellomeres gradually shorter in length. Palpus dark brown. Head dark brown, occiput with median region darker in coloration.

Thorax. Pronotum brown (Figs 3, 6). Prescutum brown with four dark brown stripes (Fig. 3). Scutum dark brown, scutellum and postnotum yellowish-brown with brighter median region (Fig. 3). Pleuron entirely brown (Fig. 6). Halter with stem yellowish-brown, knob dark brown. Leg with coxa and trochanter yellowish-brown, femur dark brown, tibia yellowish-brown, tarsus yellowish-brown except white tip. Wing suffused with grayish-brown, cells $\mathrm{c}$ and sc not darker than ground color, stigma light brown with very small bright spots on both ends; veins brown, Sc ending about opposite half length of Rs, the latter relatively short, $\mathrm{R}_{3}$ slightly curved, about twice as long as $\mathrm{R}_{2+3}$, cell $\mathrm{m}_{1} 1.6$ times longer than its petiolate, $\mathrm{r}-\mathrm{m}$ distinctly longer than basal section of $\mathrm{R}_{4+5}$ (Fig. 17).

Abdomen including hypopygium dark brown. Tergite nine conspicuously trilobed, median one cone-shaped, the other two biforked apically (Figs 41, 43). Outer gonostylus broadened in basal half, narrowed in apical half, rounded apically (Figs 41, 42, 44). Inner gonostylus with two beaks, conspicuously concaved at hind margin (Figs 41, 42, 44). Sternite eight very expanded, with deep U-shaped notch in ventral view, and densely covered with long setae (Fig. 43).

Semen pump with anterior immovable apodeme broadened, obtuse in lateral view (Figs 45, 46). Compressor apodeme spindle-shaped, relatively elongated, two times longer than anterior immovable apodeme (Figs 45, 46). Posterior immovable apodeme subequal in length to compressor apodeme, rod-shaped in dorsal view (Figs 45, 46). Aedeagal guide very developed, forming thin panel extending from semen pump posteriorly, expanded apically in lateral view, with horse-head-shaped lobe directed dorsally in lateral view (Figs 45, 46). Aedeagus relatively thick, gradually narrowed to apex (Figs 45, 46).

Differential diagnosis. The configuration of male hypopygium of $D$. (N.) setilobatoides sp. nov. is very similar to that of the Indian species $D$. (N.) setilobata Alexander, 1968 (AleXANDER 1968), but differs from the latter in broader outer gonostylus, Sc ending about opposite half the length of Rs (opposite 3/4 of length of Rs in related species), cell $\mathrm{m}_{1} 1.6$ times longer than its petiolate (cell $\mathrm{m}_{1}$ about twice as long as its petiole). There is also a noticeable difference in the shape of sternite eight, which is narrowed posteriorly in $D$. ( N.) setilobata, but relatively broad in the new species. The long setae on sternite eight is distinctively decussate crossing the mid-line in $D$. (N.) setilobata, while the midline is uncrossed in the new species.

Etymology. The specific epithet is based on the name of the related species, $D$. (N.) setilobata, with the Latin suffix '-oides', referring to the morphological similarity of the new species to its related species.

Distribution. China (Fujian Province).

\section{Dolichopeza (Nesopeza) multidentata Men sp. nov.}

(Figs 7, 10, 18, 47-57)

Type locality. Simianshan Mountain, Chongqing, China, $28^{\circ} 39^{\prime} \mathrm{N}$, $106^{\circ} 24^{\prime} \mathrm{E}$.

Type material. Holotype: CHINA: Chongqing: Simianshan Mountain, 18.v.2017, coll. Guoxi Xue, Chao Zhang. Paratypes: 1 ô 1 , same data as holotype.

Diagnosis. Generally grayish-brown. Prescutum grayish-brown with three brown stripes. Wing strongly suffused with grayish-brown, stigma dark brown, costal region and wing tip slightly darker. Leg with coxa grayish-brown, trochanter whitish, femur and tibia yellowish-white with brown tip, tarsus wholly snow-white. Tergite nine heavily blackened, with obliquely truncated lateral lobes; a deep U-shaped median notch with a small angular process medially; lateral borders of tergite produced cephalad into ridges equipped with many small blackened teeth.

Description. Male. Length: body 9.5-9.7 mm, wing 9.5-9.7 mm, antenna $5.8 \mathrm{~mm}$.

Head. Rostrum short, grayish-brown. Nasus lacking. Antenna grayish-brown, scape elongated and cylindrical, pedicel very short, flagellomeres gradually shorter in length. Palpus dark brown. Head grayish-brown with occiput darker in coloration medially.

Thorax. Pronotum wholly grayish-brown (Figs 7, 10). Prescutum grayish-brown with three brown stripes. Scutum, scutellum and postnotum grayish-brown (Fig. 7). Pleuron wholly grayish-brown (Fig. 10). Halter with stem grayish-brown, knob dark brown. Leg with coxa grayish-brown, trochanter whitish, femur and tibia yellowish-white with brown tip, tarsus wholly snow-white. Wing suffused with grayish-brown, cells $\mathrm{c}$ and sc not darker than ground color, stigma dark brown with conspicuously bright regions on both ends, costal region and wing tip darker; veins brown, Sc ending about opposite 4/5 of length of Rs, the latter relatively short, $\mathrm{R}_{3}$ slightly curved, about twice as long as $\mathrm{R}_{2+3}$, cell $\mathrm{m}_{1}$ subequal in length to its petiolate, $\mathrm{r}-\mathrm{m}$ subequal in length to basal section of $\mathrm{R}_{4+5}$ (Fig. 18).

Abdomen dark brown with yellowish ring in middle of each segment. Hypopygium dark brown. Tergite nine heavily blackened, with obliquely truncated, large lateral lobes; deep U-shaped median notch with small angular process medially; lateral borders of tergite produced cephalad into ridges equipped with many small blackened teeth (Figs 47, 48, 50). Outer gonostylus very narrowed (Figs $47,48,51)$. Inner gonostylus with basal beak truncated, with apical beak elongated and narrowed, slightly sharp at apex (Figs 47, 48, 51). Sternite nine straight (Fig. 49).

Semen pump with anterior immovable apodeme very expanded, rounded in dorsal view (Figs 52, 53). Compressor apodeme fan-shaped, relatively elongated, median ridge very developed (Figs 52, 53). Posterior immovable apodeme subequal in length to compressor apodeme, broadened basally and gradually narrowed to apex in dorsal view (Figs 52, 53). Aedeagal guide very developed, forming thin panel extending from semen pump posteriorly, expanded apically in lateral view, with folded membranous extensions on dorsal side, medially with finger-shaped process at caudal margin (Figs 52, 53). Aedeagus narrowed in basal 1/4, broadened subsequently, and then gradually narrowed to 
end, with numerous black teeth in apical half (Figs 52, 53).

Female. Length: body $9.8-10.0 \mathrm{~mm}$, wing 10.0-10.2 $\mathrm{mm}$, antenna broken.

Antenna broken, scape, pedicel and first flagellomere grayish-brown. Leg with coxa grayish-brown, trochanter whitish, femur and tibia yellowish-white with brown tip, tarsus wholly snow-white. Abdomen dark brown with yellowish ring in middle of each segment. Ovipositor brown (Figs 54, 55). Cercus long, acinacifoliate (Figs 54, 55). Hypogynial valve simple, slightly surpassing caudal margin of tergite ten, rounded apically (Figs 54, 55).

Internal reproductive system. Consisting of bursa copulatrix terminating in functional spermatheca, three spermathecae with corresponding spermatheca ducts, and vaginal apodeme (Figs 56, 57). Bursa copulatrix relatively elongated, thick; basal 2/5 folded and expanded, smoo-
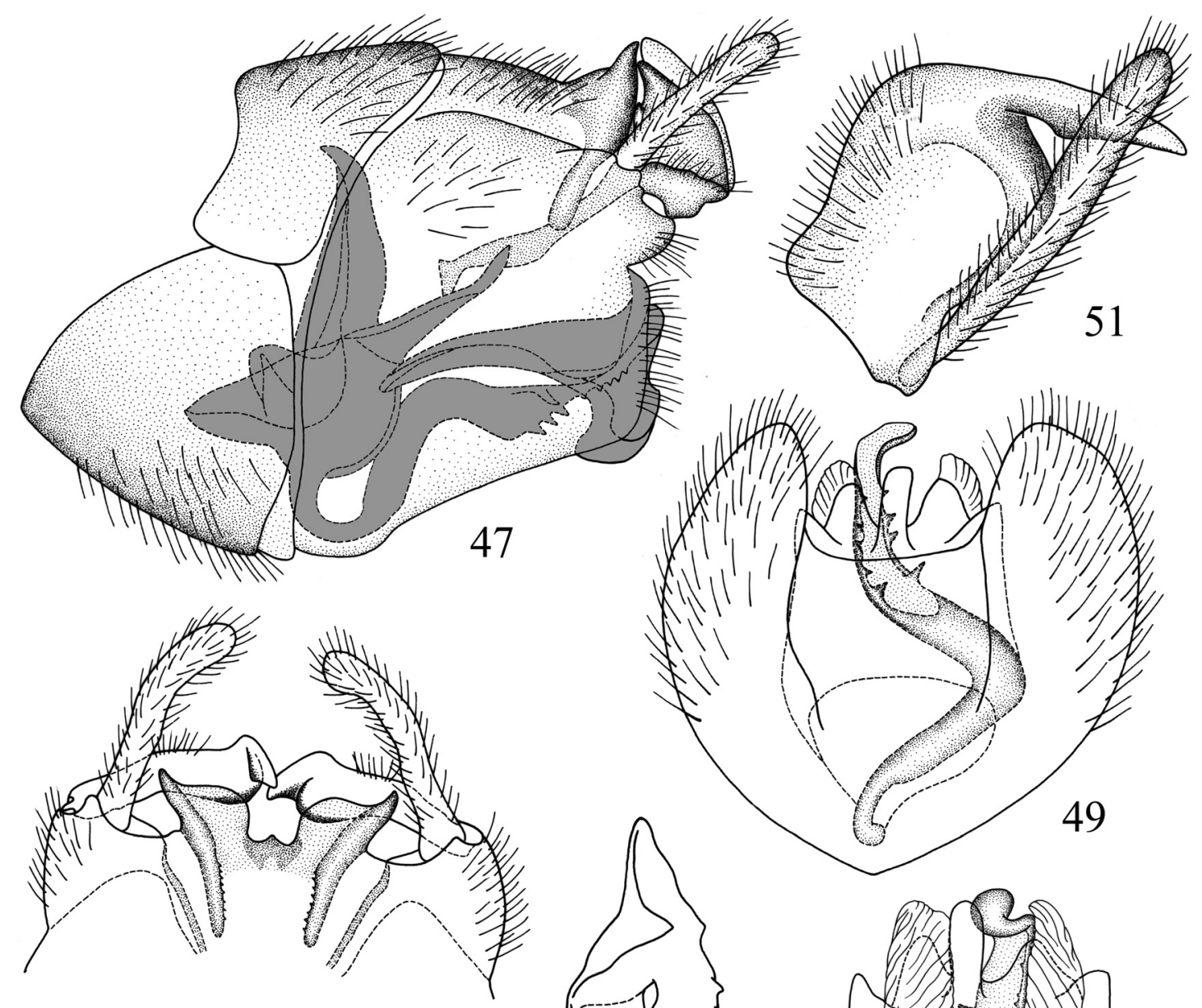

48
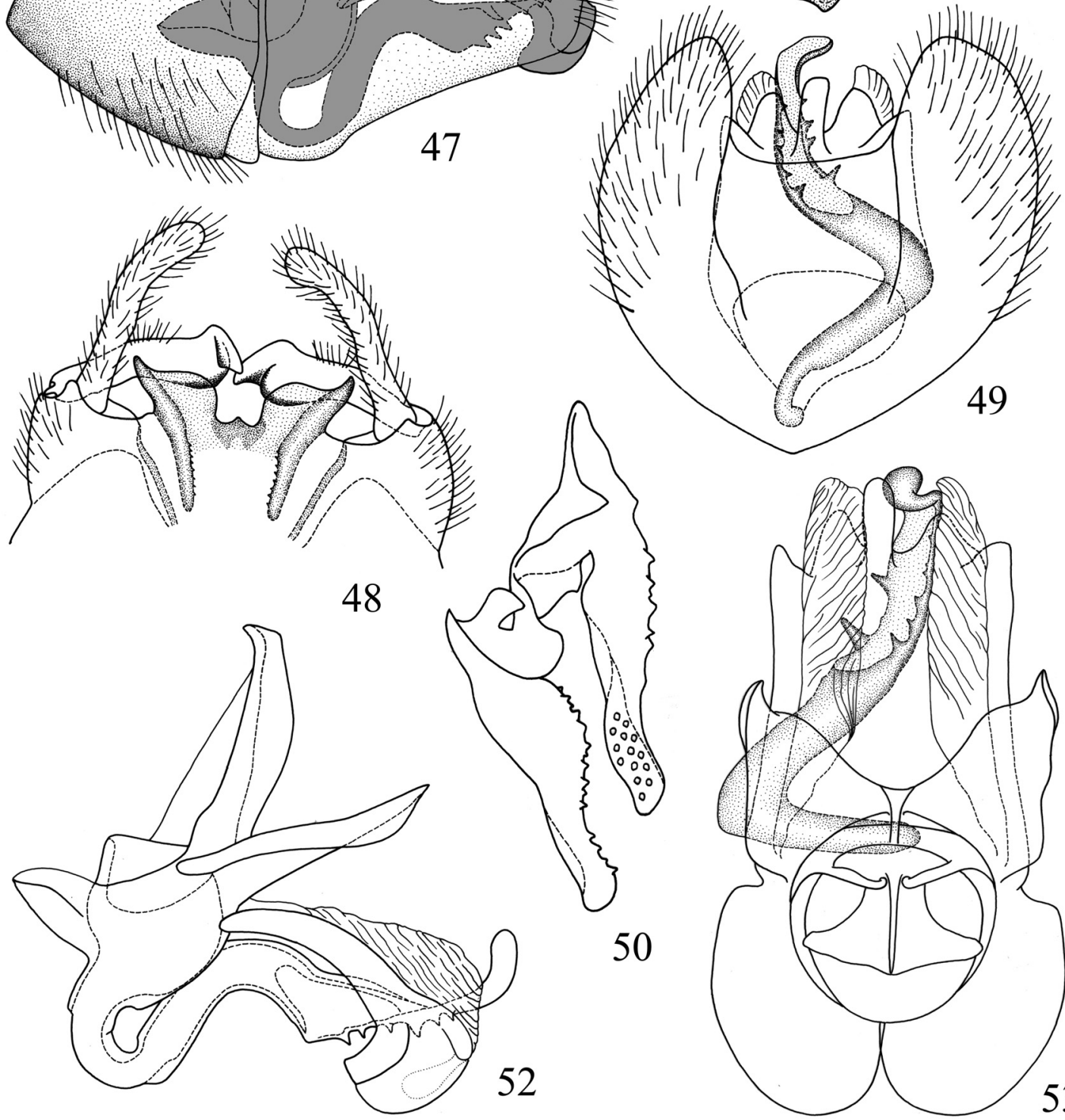

Figs 47-53. Dolichopeza (Nesopeza) multidentata sp. nov. 47 - hypopygium, lateral view; 48 - hypopygium, dorsal view; 49 - hypopygium, ventral view; 50 - tergite nine, inner view; 51 - outer gonostylus and inner gonostylus; 52 - semen pump, lateral view; 53 - semen pump, dorsal view. Gray region indicates the structure and position of semen pump. 
thed subsequently, smooth region narrowed at base and broadened apically, brown inner layer extending to distal $1 / 3$ of smooth region; bursa copulatrix terminating in elongated swollen functional spermatheca (Figs 56, 57). Spermatheca pear-shaped, black (Fig. 56). Spermatheca duct slender and flexible, generated from basal 1/3 of bursa copulatrix. Spermatheca ducts attach separately to bursa copulatrix at same level (Figs 56, 57). Vaginal apodeme strongly sclerotic, broad basally, gradually narrowed to apex (Fig. 56). Female internal reproductive system with copulatory opening on ventral side of sternite nine, very large (Fig. 56).
Differential diagnosis. The new species is mostly similar to the Chinese species Dolichopeza (Nesopeza) leucocnemis Alexander, 1940 in the shape of tergite nine and outer gonostylus, but differs from the latter in distinctly longer antenna (half that length in the related species), a small median process in the U-shaped notch (lacking such process in the related species), the outer gonostylus lacking node (with a node at base of outer gonostylus in the related species). Etymology. The specific name is derived from the Latin prefix 'multi-' and adjective 'dentata', referring to the presence of teeth on the aedeagus.

Distribution. China: Chongqing.

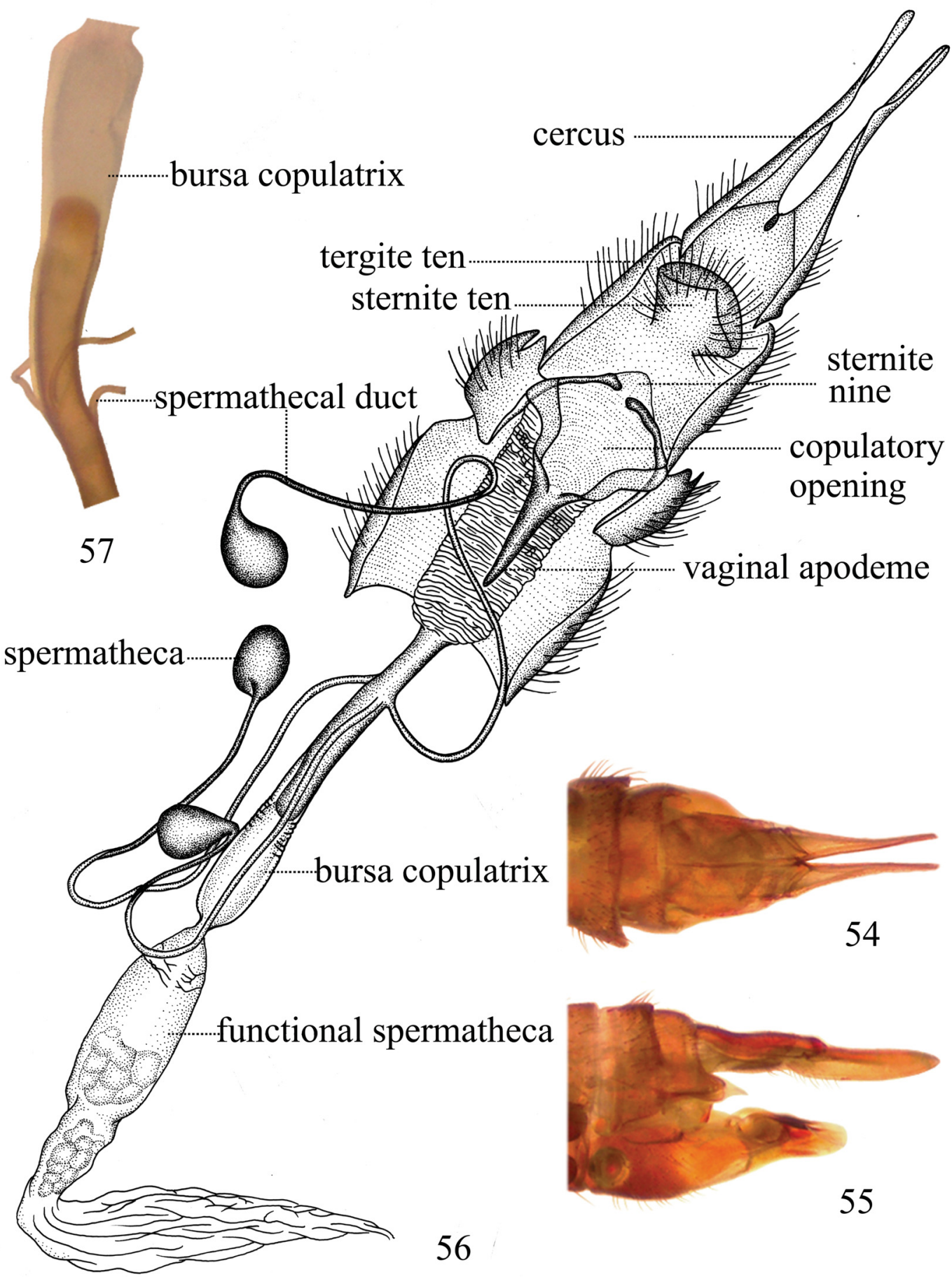

Figs 54-57. Dolichopeza (Nesopeza) multidentata sp. nov. 54 - ovipositor, dorsal view; 55 - ovipositor, lateral view; 56 - internal reproductive system; 57 - bursa copulatrix. 


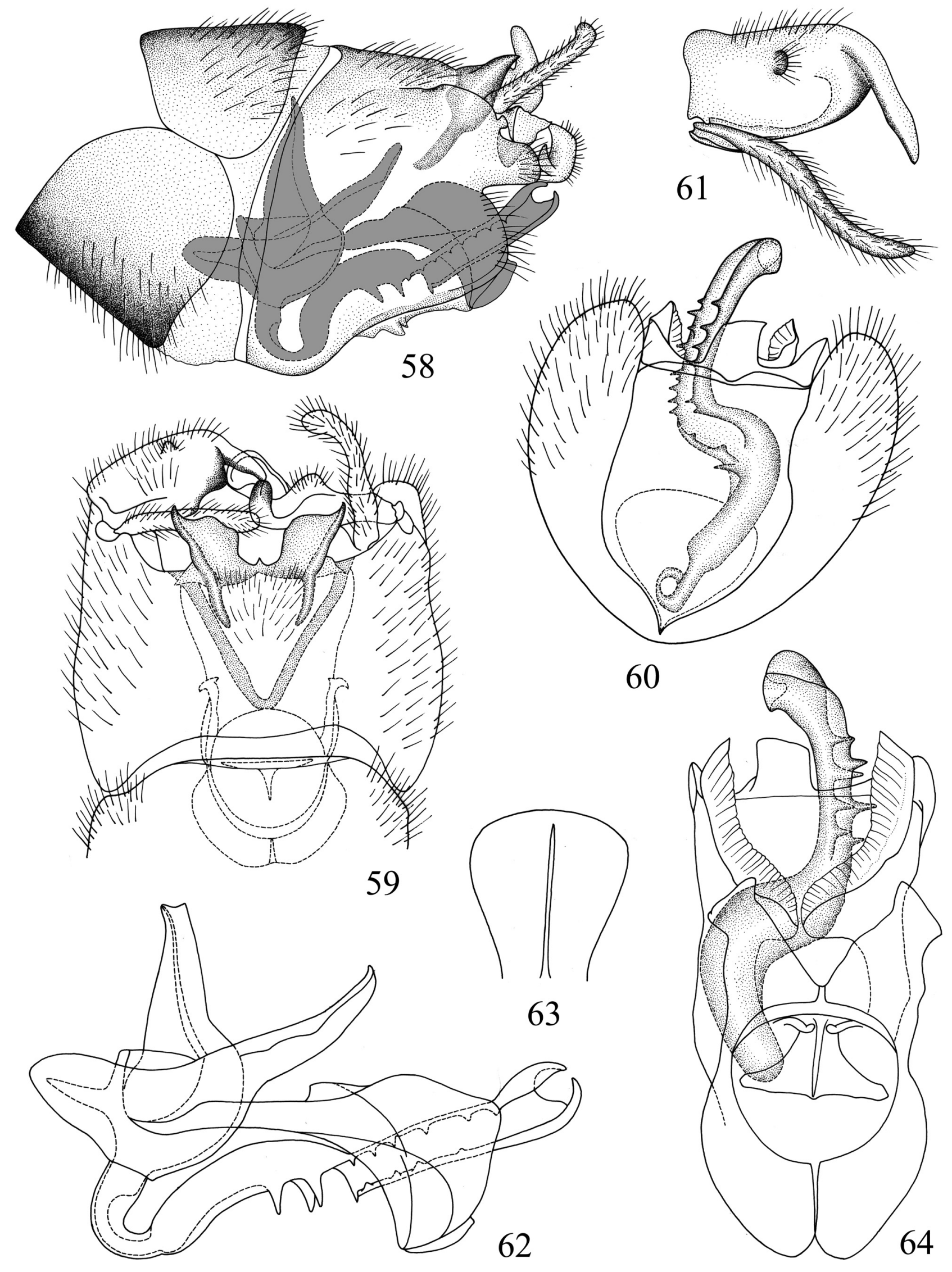

Figs 58-64. Dolichopeza (Nesopeza) medionodosa sp. nov. 58 - hypopygium, lateral view; 59 - hypopygium, dorsal view; 60 - hypopygium, ventral view; 61 - outer gonostylus and inner gonostylus; 62 - semen pump, lateral view; 63 - compressor apodeme, dorsal view; 64 - semen pump, dorsal view. Gray region indicates the structure and position of semen pump. 


\section{Dolichopeza (Nesopeza) medionodosa Men sp. nov. (Figs 8, 11, 19, 58-64)}

Type locality. Guadun, Wuyishan National Nature Reserve, Fujian Province, China, $27^{\circ} 44^{\prime} \mathrm{N}, 117^{\circ} 38^{\prime} \mathrm{E}$.

Type material. Holotype: ChinA: Fujian Province: Guadun, Wuyishan National Nature Reserve, 18.v.2017, coll. Qiulei Men. PARATYPES: $2 \hat{\jmath} \hat{\jmath}$, same data as holotype.

Diagnosis. Generally yellowish-brown. Prescutum light yellowish-brown with three light brown stripes. Wing suffused with yellowish-brown, stigma light brown, costal region and wing tip darker. Leg with coxa dark yellowish-brown, trochanter light yellowish-brown, femur yellowish-white with tip brown, tibia wholly yellowish-white, tarsus yellowish-white with the most end snow-white. Tergite nine heavily blackened, with obliquely truncated lateral lobes, having deep U-shaped notch with small median process.

Description. Male. Length: body $8.0-8.2 \mathrm{~mm}$, wing 8.0-8.2mm, antenna $4.5 \mathrm{~mm}$.

Head. Rostrum short, brown. Nasus lacking. Antenna with scape light yellowish-brown, elongated and cylindrical, pedicel yellowish-brown, very short, flagellomeres light yellowish, gradually shorter in length. Palpus yellowish. Head yellowish-brown with occiput light yellowish-brown.

Thorax. Pronotum wholly yellowish-brown (Figs 8, 11). Prescutum light yellowish-brown with three light brown stripes. Scutum light brown, scutellum and postnotum brown (Fig. 8). Pleuron wholly yellowish-brown (Fig. 11). Halter with stem light brown, knob darker in coloration. Leg with coxa dark yellowish-brown, trochanter light yellowish-brown, femur yellowish-white with tip brown, tibia wholly yellowish-white, tarsus yellowish-white with extreme tip snow-white. Wing yellowish-brown, cells c and sc slightly darker than ground color, stigma light brown with conspicuously bright regions on both ends, costal region and wing tip darker; veins brown, Sc ending about opposite 3/4 of length of Rs, the latter relatively short, $\mathrm{R}_{3}$ slightly curved, about twice as long as $R_{2+3}$, cell $m_{1}$ subequal in length to its petiolate, $\mathrm{r}-\mathrm{m}$ as long as basal section of $\mathrm{R}_{4+5}$ (Fig. 19).

Abdomen brown with yellowish ring in middle of each segment. Hypopygium dark brown. Tergite nine heavily blackened, with obliquely truncated, large lateral lobes, having deep U-shaped notch with small median process (Figs 58, 59). Outer gonostylus very narrowed (Figs 58, 59, 61). Inner gonostylus with basal beak obliquely truncated, with apical beak elongated and narrowed, slightly sharp at apex (Figs 58, 59, 61). Sternite nine straight (Fig. 60).

Semen pump very similar to that of $D$. (N.) multidentata sp. nov., with anterior immovable apodeme not so rounded in dorsal view (Figs 62-64); aedeagal guide with median process broadened, obliquely truncate apically, with shape of folded extension on ventral side not same to that of $D$. (N.) multidentata sp. nov. (Figs 62-64); aedeagus narrowed basally, broadened and curved subsequently, apical half slightly curved with lateral side opened, margins of opening with many black teeth (Figs 62-64).

Differential diagnosis. The new species is mostly similar to the Chinese species Dolichopeza (Nesopeza) leucocne- mis Alexander, 1940 in the shape of tergite nine and outer gonostylus, but differs from the latter in the existence of a small median process in the U-shaped notch (lacking such process in the related species), in cell $\mathrm{m}_{1}$ and its petiole both distinctly longer than $\mathrm{M}_{1+2+3}$ (cell $\mathrm{m}_{1}$ and its petiole both subequal in length to $\mathrm{M}_{1+2+3}$ in the related species).

Etymology. The specific name is derived from the Latin word 'medius' (= middle) and adjective 'nodosus' (= nodose), referring to the presence of node on the median region of outer gonostylus.

Distribution. China: Fujian Province.

\section{Dolichopeza (Nesopeza) jiangjinensis Men sp. nov.} (Figs 9, 12, 20, 65-71)

Type locality. Simianshan Mountain, Chongqing, China, $28^{\circ} 39^{\prime} \mathrm{N}$, $106^{\circ} 24^{\prime} \mathrm{E}$

Type material. Holotype: $\hat{\gamma}$, CHINA: Chongeing: Simianshan Mountain, 18.v.2017, coll. Guoxi Xue, Chao Zhang. Paratype: 1 o, same data as holotype.

Diagnosis. Generally yellowish-brown. Prescutum yellowish-brown with three yellow stripes. Wing light grayish, glassy, stigma light brown. Leg with coxa and trochanter yellow, femur yellowish-brown with tip darker, tibia yellowish-brown with apical $1 / 5$ whitish, tarsus wholly snow-white. Tergite nine with four processes, a pair of lateral processes horn-shaped, heavily blackened, the outer median process truncated apically, the inner median process cone-shaped, distinctly lower than the outer one; lateral borders of tergite nine produced into ridges which are broadened basally and narrowed at apical half, curved in right angle.

Description. Male. Length: body 10.0-10.2 mm, wing 10.2-10.4 mm, antenna 5.4-5.6 mm.

Head. Rostrum yellowish-brown. Nasus lacking. Antenna yellowish-brown, slightly darker than body in coloration. Palpus light yellowish-brown. Head light yellowish-brown, occiput with median region slightly darker in coloration.

Thorax. Pronotum wholly light yellowish-brown (Figs 9, 12). Prescutum light yellowish-brown with three yellow stripes (Fig. 9). Scutum, scutellum and postnotum yellowish-brown (Fig. 9). Pleuron wholly yellowish-brown (Fig. 12). Halter with stem light brown, knob darker in coloration. Leg with coxa and trochanter yellow, femur yellowish-brown with tip darker, tibia yellowish-brown with apical $1 / 5$ whitish, tarsus wholly snow-white. Wing light grayish, glassy, stigma light brown, cells c and sc not darker than ground color, stigma light brown; veins brown, Sc ending about opposite 2/3 of length of Rs, Rs relatively short, $\mathrm{R}_{3}$ slightly curved, about twice as long as $\mathrm{R}_{2+3}$, cell $\mathrm{m}_{1}$ slightly longer than its petiolate, $\mathrm{r}-\mathrm{m}$ slightly longer than basal section of $\mathrm{R}_{4+5}$ (Fig. 20).

Abdomen yellowish-brown. Hypopygium brown. Tergite nine with four processes, pair of lateral processes horn-shaped, heavily blackened, outer median process truncated apically, inner median process cone-shaped, distinctly lower than outer one; lateral borders of tergite nine produced into ridges broadened basally and narrowed in apical half, curved at right angle in genital chamber (Figs 65-67). Outer gonostylus narrowed, acute apically 
(Figs 65-68). Inner gonostylus with process horn-shaped, directed cephalad, strongly blackened, very sharp at end, with caudal process expanded, curved and terminating at acute angle (Figs 65-68). Sternite nine with pair of strongly developed processes equipped with long setae on its dorsal surface (Fig. 67).

Semen pump with anterior immovable apodeme very expanded, narrowed anteriorly, rounded laterally in dorsal view (Figs 69, 71). Compressor apodeme fan-shaped, relatively elongated, slightly darker in coloration medially (Fig. 70). Posterior immovable apodeme forming V-shaped plane, laterally terminating at obtuse angle (Figs 69, 71). Aedeagal guide thin, gradually narrowed to acute apex (Figs 69, 71). Aedeagus slightly broadened at most base, and then gradually narrowed to truncated terminal (Figs 69, 71).

Differential diagnosis. The new species is allied to the Indian species D. (N.) capitella Alexander, 1968 (ALEXAN-

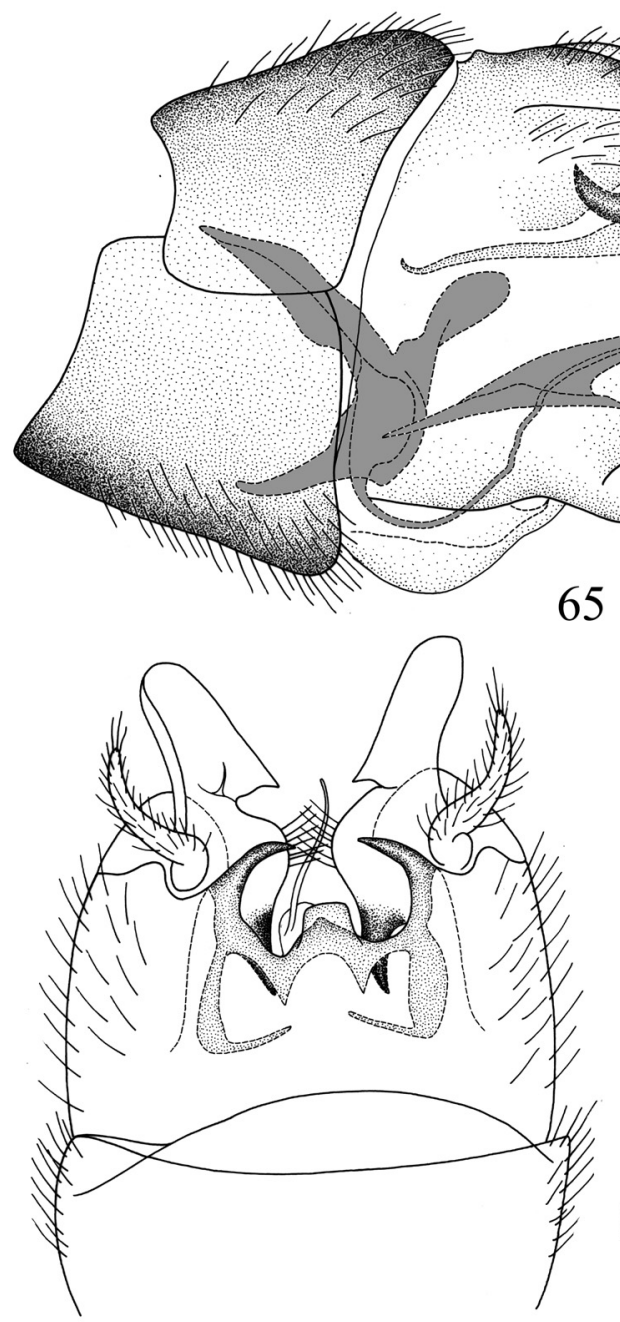

66

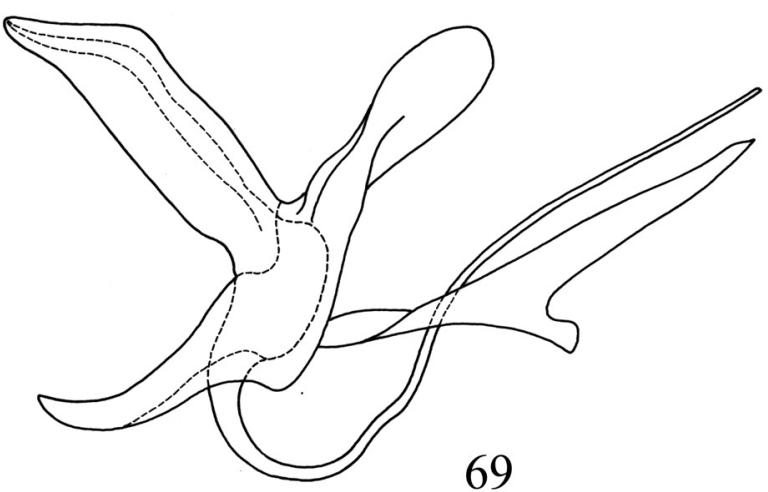

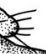
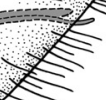

65
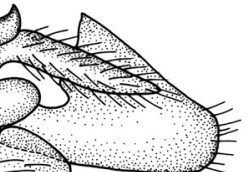
$=$

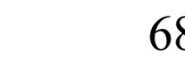

68
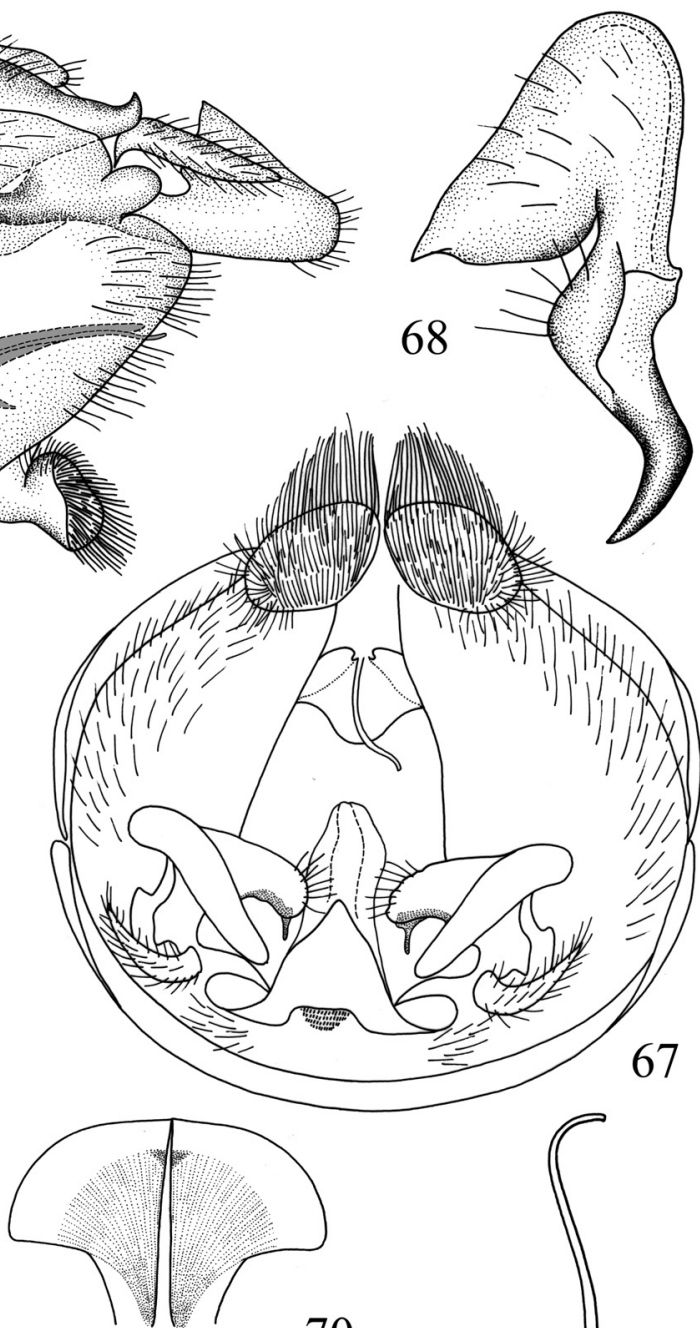

70

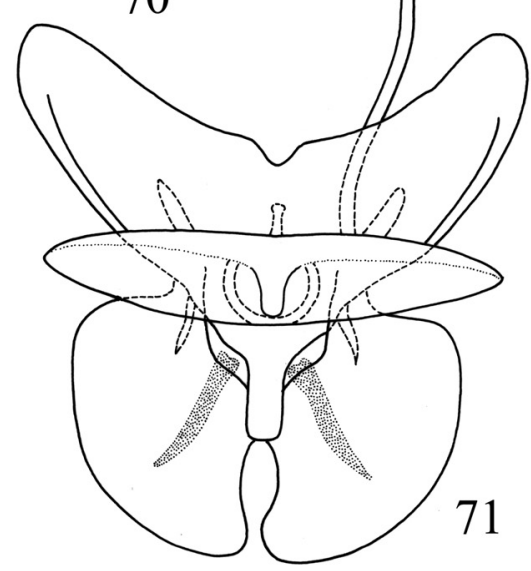

Figs 65-71. Dolichopeza (Nesopeza) jiangjinensis sp. nov. 65 - hypopygium, lateral view; 66 - hypopygium, dorsal view; 67 - hypopygium, caudal view; 68 - inner gonostylus; 69 - semen pump, lateral view; 70 - compressor apodeme, dorsal view; 71 - semen pump, dorsal view. Gray region indicates the structure and position of semen pump. 


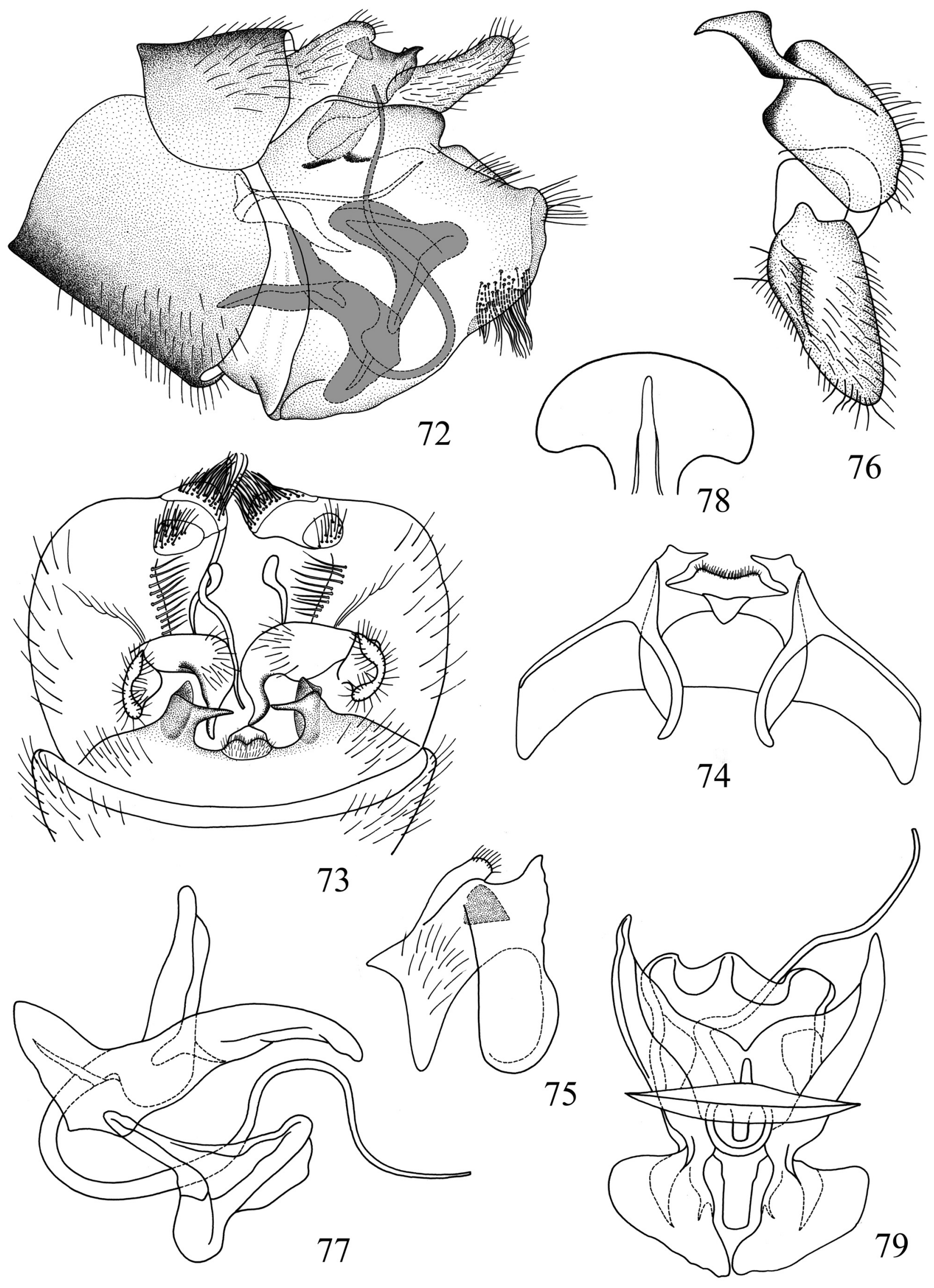

Figs 72-79. Dolichopeza (Nesopeza) lipingensis sp. nov. 72 - hypopygium, lateral view; 73 - hypopygium, dorsal view; 74 - tergite nine, inner view; 75 - tergite nine, lateral view; 76 - outer gonostylus and inner gonostylus; 77 - semen pump, lateral view; 78 - compressor apodeme, dorsal view; 79 - semen pump, dorsal view. Gray region indicates the structure and position of semen pump. 
DER 1968) by the venation of wing, the presence of hairy processes on sternite nine. It can be separated from the latter by the tergite nine with four processes (posterior border of tergite nine trilobed in $D$. ( $N$.) capitella), by the inner gonostylus with a strongly blackened and sharp beak (inner gonostylus without such beak in $D$. (N.) capitella). Etymology. The specific name refers to the type locality of the new species, Jiangjin District, Chongqing; adjective. Distribution. China: Chongqing.

\section{Dolichopeza (Nesopeza) lipingensis Men sp. nov. (Figs 13, 14, 21, 72-79)}

Type locality. Liping National Forest Park, Hanzhong, Shaanxi Province, China, $32^{\circ} 50^{\prime} \mathrm{N}, 106^{\circ} 36^{\prime} \mathrm{E}$.

Type material. Holotype: $\hat{\sigma}$, CHINA: Shannxi Province: Liping National Forest Park, Hanzhong, 12.vii.2015, coll. Guoxi Xue. PARATYPES. $2 \hat{\jmath} \hat{\jmath}$, same data as holotype.

Diagnosis. Generally yellowish-brown. Prescutum yellowish-brown with three yellow stripes. Wing with yellowish suffusion, stigma light brown. Leg with coxa and trochanter light yellowish-brown, femur yellowish-brown with apical $1 / 5$ yellowish-white, tibia wholly yellowish-white. Tergite nine with a pair of lateral processes and two median processes, the lateral process hook-shaped, heavily blackened, its inner margin with black extensions; the outer median process with V-shaped notch medially, densely covered with short setae; the inner median process cone-shaped, curved inward.

Description. Male. Length: body $8.8-9.0 \mathrm{~mm}$, wing 9.0-9.2 mm, antenna 5.4-5.6 mm.

Head. Rostrum yellowish-brown. Nasus lacking. Antenna with scape, pedicel and first flagellomere light yellowish-brown, remaining flagellomeres brown. Palpus light yellowish-brown. Head light yellowish-brown, occiput with median region slightly darker in coloration.

Thorax. Pronotum wholly yellowish-brown (Figs 13, 14). Prescutum light yellowish-brown with three yellow stripes (Fig. 13). Scutum, scutellum and postnotum yellowish-brown (Fig. 13). Pleuron wholly yellowish-brown (Fig. 14). Halter with stem light brown, knob slight darker in coloration. Leg with coxa and trochanter light yellowish-brown, femur yellowish-brown with narrowed dark tip, tibia yellowish-brown with apical $1 / 5$ yellowish-white, tarsus wholly yellowish-white. Wing yellowish with stigma light brown, color of cells $\mathrm{c}$ and sc same to the ground color; veins brown, Sc ending about opposite $2 / 3$ of length of Rs, Rs relatively short, $R_{3}$ slightly curved, about twice as long as $\mathrm{R}_{2+3}$, cell $\mathrm{m}_{1}$ slightly longer than its petiolate, $\mathrm{r}-\mathrm{m}$ slightly subequal in length to basal section of $\mathrm{R}_{4+5}$ (Fig. 21).

Abdomen yellowish-brown. Hypopygium brown. Tergite nine with pair of lateral processes and two median processes, lateral process hook-shaped, heavily blackened, its inner margin with black extensions; outer median process with V-shaped notch medially, densely covered with short setae; inner median process cone-shaped, curved inward (Figs 72-75). Outer gonostylus basally broad, narrowed to apex, with length-width ratio 2:1 (Figs 73, 76). Inner gonostylus with basal beak truncated, with apical beak hook-shaped, very sharp at end (Figs 73, 76). Sternite nine with two pairs of sclerotized planes equipped with many long setae (Figs 72, 73).

Semen pump with anterior immovable apodeme very extended laterally, narrowed anteriorly in dorsal view (Figs 77, 79). Compressor apodeme fan-shaped, relatively elongated (Fig. 78). Posterior immovable apodeme with two connected arms, forming V-shaped plane, laterally terminating in rounded terminal in dorsal view, slightly curved dorsally in lateral view; caudal margin of posterior immovable apodeme protruded medially, rounded at lateral angles (Figs 77, 79). Aedeagal guide very expanded apically (Figs 77, 79). Aedeagus thick in basal half, and then gradually narrowed to the end (Figs 77, 79).

Differential diagnosis. The new species is allied to the Indian species $D$. (N.) rahula Alexander, 1967 (AlEXANDER 1967) by the venation of wing and the shape of processes on tergite nine. It can be separated from the latter by the outer gonostylus with length-width ratio 2:1 (with length-width ratio at least $4: 1$ in $D$. (N.) rahula), by the inner gonostylus with a hook-shaped beak and truncated basal beak (inner gonostylus without such beaks in $D$. (N.) rahula).

Etymology. The specific name refers to the type locality of the new species, Liping County, Shaanxi; adjective.

Distribution. China: Shaanxi Province.

\section{Discussion}

The aedeagal guide (also named adminiculum), a strengthened portion of the intersegmental membrane between segments eight and nine, is functional as a support and guide for the intromittent organ (AlEXANDER \& BYERS 1981). It shows very high morphological diversity in shape, which offers an important tool for taxonomic study and phylogenetic analysis at different levels. Also, the position of aedeagal guide in genital chamber varies. For example, the base of aedeagal guide is connected with the anterior portion of semen pump as found in Dolichopeza, Tipula (Nobilotipula) (Frommer 1963), and Tipula (Nippotipula) (unpublished results), or separated from the semen pump as observed in Ctenophora and Tipula (Yamatotipula) (MEN \& HuAng 2014, Men et al. 2015). The terminal of aedeagal guide is not connected with sternite nine, which was observed in Ctenophora and Tipula (Yamatotipula), or lies on sternite nine, which was found in some species of Tipula (Vestiplex), Tipula (Pterelachisus), Tipula (Emodotipula), and Dolichopeza (Oropeza) (Byers 1961, Men 2015).

The apical portion of bursa copulatrix is not elongated or slightly elongated in species such as $T$. (Y.) nova, $T$. (Y.) triplex, and Nephrotoma macrocera (FrOMMER 1963, MEN et al. 2015). BYERS (1961) found that a large pouch joins the anterior end of bursa copulatrix, which is slightly far away from the attachment of spermatheca duct in subgenus Dolichopeza (Oropeza). He defined it as functional spermatheca, and suspected that the three spermathecae are generally nonfunctional in Dolichopeza, perhaps also in other Tipulinae species, because the small size of these spermathecae and great length of spermatheca ducts may delay or hinder the transmission of sperm. In the present study, the anterior end of bursa copulatrix in two Doli- 
chopeza (Nesopeza) species is very elongated and expanded. It may be functional as mentioned in Byers' hypothesis. Research of fertilization mechanisms in Dolichopeza (Nesopeza) species needs to be carried out in the future.

\section{Acknowledgments}

The authors wish to express sincere thanks to Dr. Pjotr Oosterbroek, University of Amsterdam, the Netherlands, for his valuable website, the Catalogue of the Crane flies of the World, from which we obtained a lot of valuable information. We are grateful to the staff of the Administrative Bureau of Wuyishan National Nature Reserve for their help in the course of collection. This study was supported by the National Natural Science Foundation of China (31300551), and the Anhui Outstanding Young Talent Support Program (gxfx2017059).

\section{References}

ALEXANDER C. P. 1914: Report on a collection of Japanese crane-flies (Tipulidae, Diptera). Canadian Entomologist 46: 157-164.

ALEXANDER C. P. 1928a: New or little-known Tipulidae from eastern Asia (Diptera). II. Philippine Journal of Science 35: 455-489.

ALEXANDER C. P. 1928b: New or little-known Tipulidae from eastern Asia (Diptera). III. Philippine Journal of Science 36: 455-485.

ALEXANDER C. P. 1929a: New or little-known Tipulidae from eastern Asia (Diptera). V. Philippine Journal of Science 40: 519-547.

ALEXANDER C. P. 1929b: New or little-known Tipulidae from eastern Asia (Diptera). IV. Philippine Journal of Science 40: 317-348.

ALEXANDER C. P. 1931: New or little-known Tipulidae from the Philippines (Diptera). XI. Philippine Journal of Science 46: 269-304.

ALEXANDER C. P. 1932: New or little-known Tipulidae from eastern Asia (Diptera). X. Philippine Journal of Science 49: 105-136.

ALEXANDER C. P. 1935a: New or little-known Tipulidae from eastern Asia (Diptera). XXII. Philippine Journal of Science 55: 133-164.

ALEXANDER C. P. 1935b: New or little-known Tipulidae from eastern Asia (Diptera). XXIII. Philippine Journal of Science 56: 339-372.

ALEXANDER C. P. 1937a: New or little-known Tipulidae from eastern Asia (Diptera). XXXV. Philippine Journal of Science 63: 365-404.

ALEXANDER C. P. 1937b: New or little-known Tipulidae from eastern China. Part I. Notes d'Entomologie Chinoise 4: 1-28.

ALEXANDER C. P. 1940: Studies on the Tipulidae of China (Diptera). IV. New or little-known crane-flies from Tien-mu-shan, Chekiang (cont.). Lingnan Science Journal 19: 121-132.

ALEXANDER C. P. 1942: Studies on the Tipulidae of China (Diptera). V. New crane-flies from Yunnan and Kwangtung. Lingnan Science Journal 20: 177-184.
ALEXANDER C. P. 1949: New or little-known Tipulidae (Diptera). LXXXIII. Oriental-Australasian species. Annals and Magazine of Natural History, Series 12 2: 178-205.

ALEXANDER C. P. 1956: New or little-known Tipulidae (Diptera). XCIX. Oriental-Australasian species. Annals and Magazine of Natural History, Series 12 8: 657-674.

ALEXANDER C. P. 1967: New or little-known Tipulidae from eastern Asia (Diptera). LVIII. Philippine Journal of Science 94: 535-582.

ALEXANDER C. P. 1968: New or little-known Tipulidae from eastern Asia (Diptera). LXI. Philippine Journal of Science 95: 353-400.

ALEXANDER C. P. \& BYERS G. W. 1981: Tipulidae. Pp. 153-190. In: McALPINE J. F., PETERSON B. V., SHEWELL G. E., TESKEY H. J., VOCKEROTH J. R. \& WOOD D. M. (eds.): Manual of Nearctic Diptera. Vol. 1. Biosystematics Research Institute, Ottawa, Ontario, $647 \mathrm{pp}$.

BYERS G. W. 1961: The crane fly genus Dolichopeza in North America. Kansas University Science Bulletin 42: 665-924.

FROMMER S. I. 1963: Gross morphological studies of the reproductive system in representative North American crane flies (Diptera: Tipulidae). Kansas University Science Bulletin 44: 535-625.

JONG H. DE 2017: Limoniidae and Tipulidae. Pp. 427-477. In: KIRK-SPRIGGS A. H. \& SINCLAIR B. J. (eds.) Manual of Afrotropical Diptera. Volume 2. Nematocerous Diptera and lower Brachycera. Suricata 5. South African Biodiversity Institute, Pretoria, $920 \mathrm{pp}$.

LI Y., LIU Q. F., LI T. \& YANG D. 2016: Tipulidae. Pp. 9-36. In: WU H., WANG Y. P., YANG X. K. \& YANG S. Z. (eds. in chief); YANG D., WU H., ZHANG J. H. \& YAO G. (volume eds.). Fauna of Tianmu Mountain, vol. 8. Zhejiang University Press, Hangzhou, 401 pp.

MEIJERE J. C. H. DE 1911: Studien über Sudostasiatische Dipteren, V. Ostindische Tipulidae. Tijdschrift voor Entomologie 54: 21-79.

MEN Q. L. 2015: Report on crane flies of the genus Tipula (Diptera: Tipulidae: Tipulinae) from Anhui Province, China. Acta Entomologica Musei Nationalis Pragae 55: 797-810.

MEN Q. L. \& HUNG M. Y. 2014: A new species of the genus Ctenophora Meigen (Diptera: Tipuloidea: Tipulidae) from China, with a key to the world species. Zootaxa 3841(1): 592-600.

MEN Q. L., XUE G. X. \& LIU Y. 2015: A morphological study on reproductive system of Tipula (Yamatotipula) nova Walker (Diptera: Tipulidae). Zoological Systematics 40(3): 328-338.

OOSTERBROEK P. 2017: Catalogue of the Craneflies of the World, (Diptera, Tipuloidea: Pediciidae, Limoniidae, Cylindrotomidae, Tipulidae). Available from: http://nlbif.eti.uva.nl/ccw/ (accessed 30 August 2017).

SAVCHENKO E. N. 1983: Crane-flies (Fam. Tipulidae), Introduction, and beginning of systematic part. Subfam. Dolichopezinae, subfam. Tipulinae (start). Fauna USSR. Vol. 2 (1-2). Diptera. Nauka, Leningrad, 585 pp. 
